\title{
OCORRÊNCIA ESTACIONAL DE COCCINELÍDEOS PREDADORES DE COCHONILHAS DE CARAPAÇA E DO PULGÃO PRETO NA CULTURA DOS CITROS
}

\section{JULIO CÉSAR GUERREIRO}

Engenheiro Agrônomo

Orientador: Prof. Dr. EVONEO BERTI FILHO

\author{
Tese apresentada à Escola Superior de \\ Agricultura "Luiz de Queiroz" Universidade de \\ São Paulo, para obtenção do titulo de Doutor em \\ Ciências, Área de Concentração: Entomologia
}

PIR A CICABA

Estado de São Paulo - Brasil

Fevereiro - 2004 
Dados Internacionais de Catalogação na Publicação (CIP) DIVISÃO DE BIBLIOTECA E DOCUMENTAÇÃO - ESALQ/USP

Guerreiro, Julio César

Ocorrência estacional de coccinelídeos predadores de cochonilhas de carapaça e do pulgão preto na cultura dos citros / Julio César Guerreiro. - - Piracicaba, 2004.

70 p. :il.

Tese (doutorado) - Escola Superior de Agricultura Luiz de Queiroz, 2004.

Bibliografia.

1. Coccinelídeo-predador 2. Cochonilha 3. Controle biológico 4. Fruta cítrica 5. Inseto-nocivo 6. Morte súbita 7. Pulgão I. Título

CDD 634.3 
Aos meus pais Maria e José

Pelo carinho e dedicação

OFEREÇO

Ao meu irmão e à minha companheira Cris Pelo convívio, compreensão e amor. 


\section{AGRADECIMENTOS}

\section{A Deus;}

Ao Prof. Dr. Evoneo Berti Filho pelo exemplo de honestidade, profissionalismo e pelos conhecimentos dispensados para a realização deste trabalho;

Ao Prof. Dr. Antonio Carlos Busoli pela amizade demonstrada durante todo período estudantil e profissional, e pela co-orientação nesta e em outras pesquisas;

Aos professores do Departamento de Entomologia, Fitopatologia e Zoologia Agrícola ESALQ/USP, pelos conhecimentos dedicados;

Ao Prof. Dr. José Carlos Barbosa pela orientação nas análises estatísticas;

Ao Biólogo Heraldo Negri de Oliveira, pelas fotos apresentadas neste trabalho;

A todos os amigos do curso de Pós-Graduação, pela amizade nos bons momentos convividos;

Aos amigos Fábio, Lília, Rodrigo, Francisco, Amílcar, pelas sugestōes, trabalhos realizados e companheirismo;

À Escola Superior de Agricultura "Luiz de Queiroz" (ESALQ) e ao Departamento de Entomologia, Fitopatologia e Zoologia Agrícola, pela oportunidade de realização do curso;

À Faculdade de Ciências Agrária e Veterinárias de Jaboticabal, pela receptividade na realização de parte de minha Tese;

A todos que direta ou indiretamente colaboraram para a realização deste Trabalho. 


\section{SUMÁRIO}

Página

RESUMO

SUMMARY...

viii

1 INTRODUÇÃO.

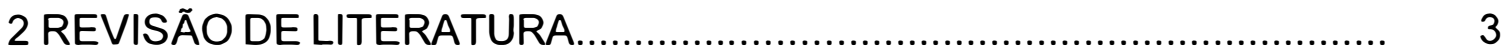

2.1 Caracterização geral da familia Coccinellidae..................................... 3

2.2 Características taxonômicas gerais........................................................ 5

2.3 Estágios de desenvolvimento......................................................... 7

2.4 Local de desenvolvimento................................................................ 9

2.5 Hábito alimentar de Coccinellidae...................................................... 11

2.6 Os coccinelídeos como predadores em agroecossistemas.................. 14

2.7 A importância dos coccinelídeos no agroecossistema citrícola............. 18

3 OCORRÊNCIA ESTACIONAL DE Coccidophilus citricola BRĖTHES, 1905 (COLEOPTERA: COCCINELLIDAE) E DE SUAS PRINCIPAIS PRESAS NA CULTURA DOS CITROS.................................................. 24

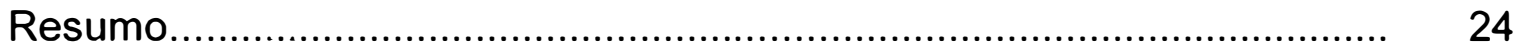

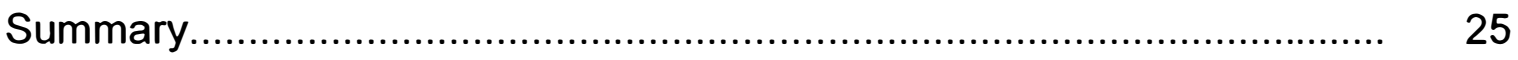

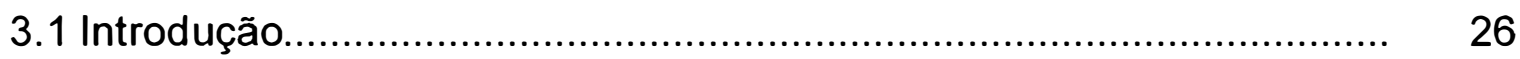

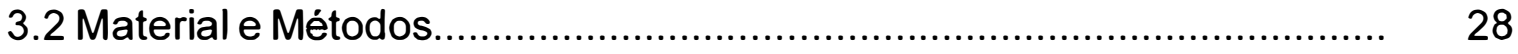

3.3 Resultados e Discussão............................................................... 30

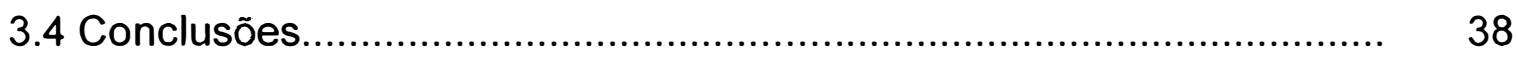

4 OCORRÊNCIA ESTACIONAL DAS PRINCIPAIS ESPÉCIES DE COCCINELLIDAE PREDADORAS DE Toxoptera citricida (KIRKALDY, 
1907) (HEMIPTERA: APHIDIDAE) NA CULTURA DOS

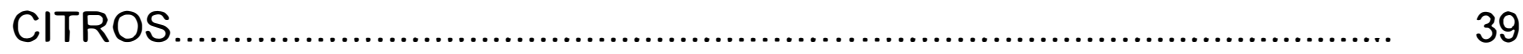

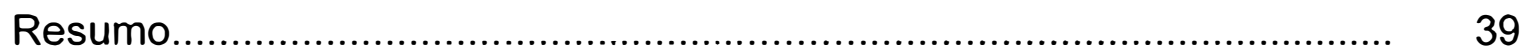

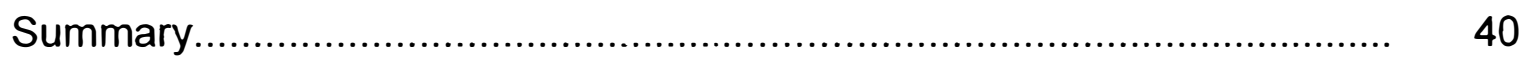

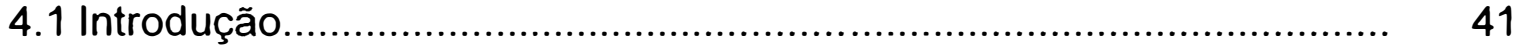

4.2 Material e Métodos..................................................................... 43

4.3 Resultados e Discussão....................................................... 45

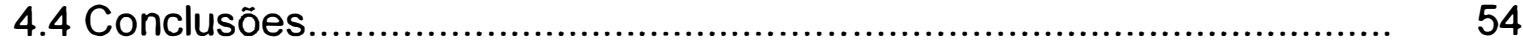

5 CONCLUSÕES GERAIS........................................................ 55

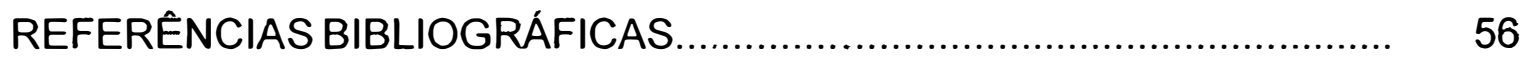




\title{
OCORRÊNCIA ESTACIONAL DE COCCINELÍDEOS PREDADORES DE COCHONILHAS DE CARAPAÇA E DO PULGÃO PRETO NA CULTURA DOS CITROS
}

\author{
Autor: JULIO CÉSAR GUERREIRO \\ Orientador: Prof. Dr. EVONEO BERTI FILHO
}

\section{RESUMO}

A família Coccinellidae é composta, na sua maioria, por insetos predadores de pragas, nos mais variados agroecossistemas. Neste contexto, o presente trabalho teve o objetivo de determinar as espécies mais importantes de coccinelídeos predadores de cochonilhas de carapaça e do pulgão preto dos citros, bem como determinar a correlação de ocorrência destes predadores e de suas presas nas diferentes estações do ano. Foram avaliadas plantas de citros em um pomar comercial, localizado no município de Taiúva, SP. As amostragens foram realizadas quinzenalmente, durante o período de março/2002 a fevereiro/2003, utilizando 25 plantas ao acaso. Observou-se que a joaninha Coccidophilus citricola (Coleoptera: Coccinellidae), teve ocorrência constante no pomar, sendo correlacionada com as cochonilhas Parlatoria ziziphus e P. cinérea (Hemiptera: Diaspididae). Já os coccinelídeos Diomus sp. e Cycloneda sanguinea (Coleoptera: Coccinellidae), que tiveram, também, ocorrência constante no pomar, mostraram correlação com a ocorrência do pulgão preto dos citros Toxoptera citricida (Hemiptera: Diaspididae). 


\title{
SEASONAL OCCURRENCE OF. COCCINELLIDS PREYING SCALE PESTS AND THE BROWN CITRUS APHID
}

\author{
Autor: JULIO CÉSAR GUERREIRO \\ Orientador: Prof. Dr. EVONEO BERTI FILHO
}

\section{SUMMARY}

This research was carried out in order to determine the most important coccinellid species preying scale insects and the brown citrus aphid, as well as the correlation of the occurrence of these predators and their preys in the different seasons of the year. Fortnightly samples were randomly taken from 25 plants of a citrus commercial orchard located in Taiuva, State of SãoPaulo, Brazil, from March 2002 to February 2003. It was observed that Coccidophilus citricola (Coleoptera: Coccinellidae) was constant and correlated with Parlatoria ziziphus and $P$. cinerea (Hemiptera: Diaspididae). The species Diomus sp. and Cycloneda sanguinea (Coleoptera: Coccinellidae) were also constant ones and showed correlation with the brown citrus aphid, Toxoptera citricida (Hemiptera: Aphididae). 


\section{INTRODUÇÃO}

A importância da citricultura é destacada no Brasil devido a geração de divisas com a exportação de suco concentrado ou fruta "in natura", o que tem implicado em maior renda interna e empregos (Nascimento et al., 1982; Neves, 1992; Borges \& Almeida, 2000; Agrianual, 2002).

As pragas agrícolas fazem parte dos fatores limitantes para as diversas culturas implantadas, não sendo diferente para a cultura dos citros, destacando-se dentre estas, cochonilhas, mosca-das-frutas, mosca branca, cigarrinhas, coleobrocas, tripes, lagartas e pulgões, além de outros artrópodes como ácaros fitófagos (Gravena, 1984; Busoli, 1992; Pinto W.B.S., 1995; Paiva, 2000; Dantas, 2002; Ribeiro, 2002).

$\mathrm{Na}$ tentativa de maximizar a produção e preservarem seus pomares de pragas agrícolas, os produtores rurais passaram a utilizar o controle químico de forma intensa, causando desequilíbrio no agroecossistema, como a morte de inimigos naturais (predadores e parasitóides), além de causar problemas de saúde para produtores rurais e consumidores (De Bach, 1964; Gravena \& Lara, 1976; Dean et al., 1983; Gravena, 1990; Busoli, 1992).

Nesta condição de desequilíbrio no agroecossistema é que o controle biológico de pragas, utilizado como tática e estratégia do manejo integrado de pragas, surge como uma das alternativas para a diminuição do desequilíbrio biológico, aumento da qualidade de vida de agricultores e consumidores de produtos agrícolas, além de ser, muitas vezes, mais econômico que a aplicação de inseticidas (De Bach, 1964; Berti Filho, 1990). 
Dentre os inimigos naturais, os coleópteros da família Coccinellidae se destacam por serem, na sua maioria, espécies predadoras de inúmeras pragas agrícolas pertencentes às mais variadas ordens, como Hemiptera, Lepidoptera, Coleoptera, Diptera e Thysanoptera.

Os coccinelídeos são cosmopolitas, sendo encontrada nos mais variados ecossistemas do mundo. São insetos que fazem parte da história do controle biológico clássico de pragas, que se deu a partir da introdução da joaninha Rodolia cardinalis (Mulsant) da Austrália para vários países no mundo, para o controle da cochonilha Icerya purchasi Maskell (Caltagirone \& Doutt, 1989).

No agroecossistema citrícola, os coccinelídeos destacam-se como bons predadores de pragas primárias e secundárias, como cochonilhas, pulgões e ácaros (Gravena, 1986; Berti Filho, 1990; Busoli, 1992; Guerreiro, 2000). No entanto, pouco se sabe sobre as espécies brasileiras presentes e atuantes neste agroecossistema, bem como a correlação de sua ocorrência com a ocorrência das pragas agrícolas.

O presente trabalho teve como objetivo determinar as principais espécies de coccinelídeos predadores de cochonilhas de carapaça e pulgões que ocorrem no agroecossistema citrícola, bem como determinar a correlação entre a ocorrência destes predadores e suas presas. 


\section{REVISÃO DE LITERATURA}

\subsection{Caracterização geral da família Coccinellidae}

Os insetos pertencentes à familia Coccinellidae são, no Brasil, comumente chamados de joaninhas (Araujo, 1940), possuem grande empatia popular, sendo em muitos países considerados organismos símbolos de felicidade, serenidade e sorte (Hodek, 1973). As joaninhas chamam atenção devido ao padrão de coloração apresentado por seus élitros, que, na maioria das vezes, são brilhantes com diferentes modelos de distribuição de manchas. São sempre bem vindas em jardins, pequenos bosques, e, até mesmo, em vasos de flores. No entanto, segundo Vanderberg (1987), a importância deste inseto é maior no controle biológico de pragas agrícolas.

Os coccinelídeos são cosmopolitas, sendo encontrados nos mais variados ecossistemas do mundo, tais como: tundra, florestas, pastagens, cerrados e agroecossistemas em geral. São insetos adaptados a diferentes condições ambientais, tendo comportamento diferenciado de acordo com o nicho ecológico ocupado (Iperti, 1999).

Segundo Gordon (1985) e Olkowski et al. (1990), a família Coccinellidae é uma das maiores famílias da ordem Coleoptera, que inclui, aproximadamente, 490 gêneros e mais de 5000 espécies, sendo a maioria destas predadoras, apresentando esta característica tanto na fase larval, como na fase adulta. 
As joaninhas alimentam-se de pulgões, moscas branca, cochonilhas, tripes, ácaros, lagartas desfolhadoras em fases iniciais, entre outros artrópodes pequenos (Hagen, 1962; Hodek, 1973; Kuznetsov, 1997). São insetos predadores bem aceitos no controle biológico de pragas agrícolas, sendo o primeiro predador a ser utilizada no controle biológico clássico de pragas no mundo.

O controle da cochonilha Icerya purchasi, pela introdução da joaninha Rodolia cardinalis em pomares de citros da Califórnia (EUA), em 1889, representou um marco na história do controle biológico clássico de pragas agrícolas utilizando um predador introduzido de outro país, caso que não teve paralelo, considerando a época em questão, o interesse humano e as ramificações políticas desenvolvidas neste período (Caltagirone \& Doutt, 1989).

Segundo Iperti (1999), o sucesso do controle biológico clássico utilizando $R$. cardinalis é exemplo citado e seguido até os dias atuais, pois este predador foi introduzido da Austrália para 33 paises, obtendo sucesso em 26 destes.

O interesse no uso de coccinelídeos no controle biológico tem sido aumentado com o decorrer dos anos. Segundo Kusnetsov (1997), em muitos países estes predadores têm alcançado grande sucesso no controle de pragas que ocorrem em culturas agrícolas, florestais e ornamentais.

Entre os vários casos de sucesso de introdução de agentes entomófagos, para o controle biológico de pragas agrícolas, os coccinelídeos foram utilizados com bons resultados em 51 destes, sendo a maioria composta por predadores de cochonilhas (De Bach, 1964; Iperti, 1999).

De acordo com Hodek (1973) e Hodek \& Honek (1996), o maior sucesso dos coccinelídeos que predam cochonilhas se dá devido ao comportamento destas espécies. São insetos que permanecem na mesma área durante seu desenvolvimento, visto que suas presas são sésseis, comparadas com os pulgões, por exemplo, e pelas espécies de joaninha predadoras destes 
organismos, que segundo Obrycki \& Kring (1998) são insetos tipicamente mais móveis, e que apresentam maior polifagia.

\subsection{Características taxonômicas gerais}

Coccinellidae é pertencente à superfamília Cucujoidea, e, provavelmente, devido ao seu intenso e diferente padrão de coloração, tenham chamado a atenção de vários naturalistas, como Linnaeus, que foi o primeiro sistemata a descrever espécies de coccinelídeos do gênero Coccinella na Europa (Kusnetsov, 1997).

A família Coccinellidae foi estabelecida e descrita por Latreille em 1807, tendo a partir deste período várias espécies estudadas e descritas por vários pesquisadores sistematas como: Mulsant, Korschefsky, Mader, Cotch e Weise, entre outros, sendo estes dois últimos, os pesquisadores responsáveis pelo desenvolvimento e publicação de chaves para a determinação de espécies presentes na Europa (Sasaji, 1971).

De acordo com Kusnetsov (1997), Weise em 1885 foi o pesquisador sistemata que primeiro utilizou a genitália masculina para a identificação de espécies de coccinelídeos. Até então, os insetos eram separados em espécies, pelos diferentes padrões de coloração apresentados nos élitros, que segundo Hodek (1973) e Hodek \& Honek (1996), é uma forma errônea de identificação, pois o padrão de coloração dos élitros pode variar entres os indivíduos de mesma espécie, sejam eles de mesmo sexo, ou de sexo diferente.

Após estes trabalhos, os sistematas passaram a utilizar a genitália masculina e feminina, para a identificação das espécies de coccinelídeos (Vanderberg, 1987).

Com uma diferente forma de classificação, que se baseava nas características de larvas e adultos, Sasaji (1971) dividiu a família Coccinellidae 
em seis subfamílias: Sticholotinae, Scymninae, Chilocorinae, Coccidulinae, Coccinellinae e Epilachninae (Figura 1).

Segundo Hodek (1973), Iperti (1999) e Hodek \& Honek (1996), a característica principal que influencia na separação em subfamílias é o hábito alimentar. As subfamílias Coccinellinae e Epilachninae são as mais avançadas evolutivamente, e a última representada por indivíduos fitófagos.

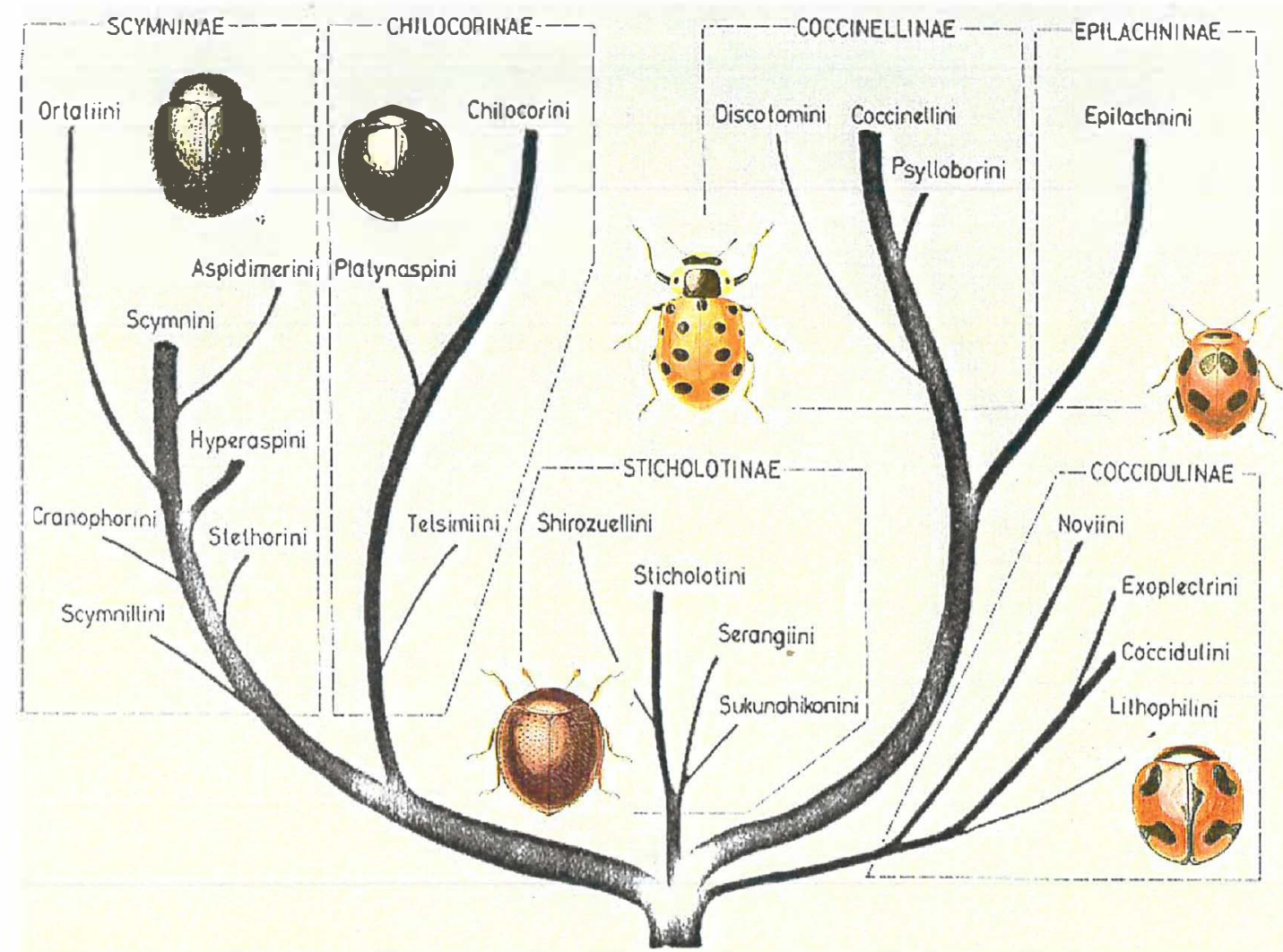

Figura 1 - Dendrograma para subfamílias e tribos da família Coccinellidae, com exemplos de espécies de cada subfamília. (Adaptado de Sasaji, 1971)

A maioria das subfamílias, ou seja, Coccidulinae, Coccinellinae, Epilachninae, Scymninae e Sticholotinae, foram relatadas por Chaves et al. (1991), para o Brasil. Além destas, Chilocorinae foi referida e estudada por pesquisadores que visaram a criação massal de insetos, para o controle da cochonilha Diaspis echinocacti, praga que ataca a palma forrageira no Nordeste brasileiro (Arruda Filho \& Arruda, 2002). 
Apesar do aumento de sistematas especialistas em Coccinellidae, desenvolvendo os estudos de classificação e identificação no Brasil e no mundo, o que implica em constante aumento do número de espécies dentro da família, pouco se tem feito para favorecer, ou facilitar a identificação de insetos desta família no campo (Guerreiro, 2000).

A maioria dos agricultores, mesmo conhecendo o benefício do controle biológico de pragas dentro de um sistema de manejo integrado de pragas, não consegue, na prática, separar ou distinguir os insetos predadores de insetos pragas (Guerreiro et al., 2002). Neste contexto, um eficiente trabalho de extensão, demonstrando ao agricultor as diferenças básicas entre pragas e inimigos naturais, pode ter como resultado o aumento de inimigos naturais no agroecossistema, que é um dos preceitos básicos do manejo integrado de pragas (Berti Filho, 1990)

\subsection{Estágios de desenvolvimento}

Coccinellidae possui metamorfose completa. Os ovos têm formato ovalado, com padrão de coloração variando, do amarelado ao avermelhado. São colocados em diferentes locais, de acordo com o comportamento de cada espécie (Sasaji, 1971). Podem ser depositados em massas ou isoladamente, na superfície de folhas, próximos de colônias de presas, e, ainda, sob carapaça de cochonilhas já consumidas (Guerreiro, 2000). Segundo Guerreiro et al. (2001) e Guerreiro et al. (2003), o comportamento de ovipositar sob carapaça de cochonilhas já predadas, provavelmente, visa proteger a prole da variação dos fatores ambientais, dificultar a atuação de predadores e parasitóides, $s$ segundo Silva et al. (2001) proteger os ovos e larvas jovens, que poderiam ser contaminadas por ocasião da aplicação de agrotóxicos, usados para o controle de pragas nos agroecossistemas. 
As larvas neonatas permanecem próximas das oviposições, alimentando-se de cório de ovos que já tiveram as larvas eclodidas, ou mesmo, de ovos contendo o embrião e larvas mais novas (Hodek, 1973; Hodek \& Honek, 1996). Segundo Hodek (1967), este comportamento de canibalismo observado para Coccinellidae é freqüente e importante, pois pode garantir a sobrevivência da espécie em épocas de pouca ocorrência de presas no campo, diminuindo a pressão por alimento, e selecionando os indivíduos mais adaptados ao meio.

No entanto, este comportamento pode ser um entrave no desenvolvimento de uma criação massal de coccinelídeos em laboratório (Santos, 1995; Guerreiro, 1998), pois implica em diminuição de número de descendentes em cada geração (Guerreiro, 2000; Silva, 2002).

As larvas são do tipo campodeiforme, adaptadas ao rápido caminhamento em busca de presas. São observados, em geral, quatro ínstares larvais.

A fase larval de Coccinellidae tem um interessante comportamento de defesa, ou seja, as larvas de qualquer instar podem liberar, através de estruturas secretoras localizadas nas pernas (entre o fêmur e a tíbia), uma substância amarelada e impalatável, constituindo-se uma das primeiras e mais importantes formas de defesa contra seus inimigos naturais, sejam eles insetos, outros artrópodes ou mesmo aves (Hagen, 1962).

A pupa pode ser coberta parcial ou totalmente pela exúvia do último estádio larval. É do tipo livre ou exarada podendo apresentar algum tipo de movimento, se perturbada (Hodek \& Honek 1996). Geralmente os coccinelideos possuem o comportamento de puparem uns próximos aos outros, em reentrâncias apresentadas pelos substratos, onde estão presentes as presas (Guerreiro, 2000)

Ao emergir, o adulto apresenta o corpo claro, no entanto já podem ser observadas manchas características de cada espécie. De forma gradual o élitro vai adquirindo a coloração, bem como a espessura e a dureza característica 
apresentada por indivíduos adultos da espécie (Correia \& Berti Filho, 1988). Neste periodo, observa-se que os adultos permanecem sobre a exúvia pupal, sem apresentar qualquer tipo de movimentação. No entanto, tão logo adquirem a coloração normal da espécie, e apresentem seus élitros endurecidos, saem, ávidos, em busca de alimentos, atacando a primeira presa, que porventura, esteja mais próxima, mesmo que não seja o alimento ideal (Guerreiro, 2000).

\subsection{Local de desenvolvimento}

Os coccinelídeos podem ser restritos a determinados ambientes, ou ter a capacidade de sobreviver e desenvolver em uma ampla variedade de condições ambientais (Hodek, 1973; Futuyma, 1997; Iperti, 1999). A especificidade em determinado hábitat pode ocorrer ou não para Coccinellidae e como exemplo, pode-se citar as espécies Adalia bipunctata L., Coccinella septempunctata Mulsant e Cycloneda sanguinea (L.), como joaninhas presentes em variados tipos de hábitats, alimentando-se de muitas espécies de afídeos e em alguns casos, pólen das plantas hospedeiras (Hodek \& Honek, 1996; Guerreiro et al. 2002). Enquanto que Coccidophilus citricola Brèthes e Pentilia egena Mulsant parecem ter maior especificidade em termos de hábitat e presa, pois segundo Santos (1995), Guerreiro (2000) e Silva (2002) são espécies de ocorrência quase que restrita aos pomares citrícolas.

Segundo Iperti (1999), um ambiente pode ser considerado ideal ou ser um hábitat típico, se este local for capaz de atrair coccinelídeos adultos $e$ favorecer a oviposição e o desenvolvimento das larvas e pupas.

Vários fatores podem ser considerados na escolha de um determinado

local ideal para os coccinelídeos desenvolverem-se e reproduzirem-se, no entanto, segundo Hodek (1967) a presença de presas essenciais e as condições microclimáticas ideais são consideradas como os mais importantes. 
Além das condições descritas anteriormente, Iperti (1999) cita que o tipo de vegetação e o estrato dentro deste tipo de vegetação podem atuar na escolha do local preferido para desenvolvimento e reprodução. Neste contexto, Iperti (1965) observou que coccinelídeos de espécies diferentes eram atraídos por estratos diferentes, dentro de uma mesma planta, cuja presa era considerada ideal.

De acordo com van den Bosch et al. (1959) e Hodek (1967), outros fatores, não tão importantes como aqueles citados anteriormente, podem exercer certa influência na escolha do hábitat para os coccinelídeos viverem e se desenvolverem, como a existência de hábitats adjacentes ou áreas de refúgio. Segundo estes autores os coccinelídeos são atraídos para determinado hábitat, seja ele um jardim, plantio de uma cultura anual, ou um pomar de frutiferas com maior probabilidade, se próximo deste, houver áreas consideradas refúgios.

As áreas consideradas refúgios podem ser matas, florestas implantadas, jardins, ou mesmo um plantio agrícola, desde que possam fornecer alimentos essenciais ou alternativos, ou mesmo um local para abrigo, durante períodos desfavoráveis em termos de alimentação, como épocas de entressafra, ou clima desfavorável (Sloggett \& Majerus, 2000).

Os coccinelídeos sempre necessitam de locais alternativos, que atuem na ligação de um determinado hábitat a outro, pois a maioria dos coccinelídeos, principalmente aqueles que se alimentam de afídeos, não permanecem num determinado local durante o ano todo. Aqueles considerados afidófagos são os insetos que possuem maior necessidade ou capacidade de se dispersarem, visto que os afídeos podem ser considerados como um tipo de presa com relativa mobilidade, quando comparados com cochonilhas, ácaros e psilídeos (Dixon et al., 1997; Holst \& Ruggle, 1997; Rosenheim et al., 1997).

Devido às características das presas e do próprio predador apresentadas anteriormente, os coccinelídeos afidófagos vivem sempre em busca de hábitats melhores e mais convenientes para os adultos e sua prole. 
Por este motivo, Hodek (1973), Hodek \& Honek (1996) e Iperti (1999), descrevem vários casos de insucesso da implantação de controle biológico clássico de pragas, envolvendo coccinelídeos afidófagos, o contrário do que se observa para as espécies predadoras de pragas agrícolas mais sedentárias, como as cochonilhas.

\subsection{Hábito alimentar de Coccinellidae}

O comportamento alimentar apresentado por coccinelídeos tem sido muito estudado, visto que apresentam características importantíssimas, seja na atuação no controle de pragas, mantendo estes insetos em um nível que não causem prejuízos ao agroecossistema, ou em menor grau, no ataque de plantas cultivadas, por espécies fitófagas.

Segundo Hodek \& Honek (1996) os coccinelídeos predadores possuem uma larga cadeia de alimentos aceitáveis. Além de alimentarem-se de insetos da ordem Hemiptera e de ácaros fitófagos, podem predar fases jovens de espécies pertencentes as ordens Lepidoptera, Coleoptera, Hymenoptera, Diptera e Thysanoptera.

Entre as diferentes espécies ocorre considerável variação e especificidade em hábitos alimentares. Cada subfamília dentro da família Coccinellidae possui uma categoria de alimento predominantemente preferivel, tendo espécies que se alimentam de cochonilhas, afídeos, ácaros, fungos e plantas.

A maioria dos insetos das subfamílias Sticholotinae, Coccidulinae e Chilocorinae, se alimenta de cochonilhas, principalmente daquelas pertencentes à família Diaspididae; entre os coccinelídeos da subfamília Scymninae, existem espécies que se alimentam de ácaros, pulgões e cochonilhas (Sasaji, 1971). 
Já para Coccinellinae, nota-se que a maioria das espécies alimenta-se de pulgões, com algumas exceções, como as espécies pertencentes à tribo Psylloborini, que são especialistas em fungos (Almeida, 1992). A subfamilia Epilachninae e, mais precisamente, a tribo Epilachnini é totalmente fitófaga, tendo uma grande tendência em atacar plantas cucurbitáceas (Hodek \& Honek, 1996; Iperti, 1999).

Para consumir sua presa, a joaninha permanece sobre seus alimentos, quando estes são insetos imóveis, como cochonilhas (Silva, et al. 2001), ou saem em busca de suas presas até conseguir capturá-las, como no caso de pulgões e ácaros (Romero et al. 1974).

De acordo com Iperti (1999) as joaninhas adultas podem alimentar-se total ou parcialmente do corpo de sua presa, seja a parte líquida ou a sólida. No entanto, as larvas alimentam-se de algumas porções do corpo destes insetos, e quando saciadas podem liberar suas presas, ainda vivas, mas moribundas, devido aos ferimentos que na maioria das vezes paralisam sua alimentação, causando a morte num curto período de tempo.

Segundo Silva et al. (2001) o conteúdo líquido do corpo da presa é aspirado e re-introduzido no corpo da mesma pelos coccinelídeos, repetidas vezes, até que reste apenas o tegumento, que na maioria das vezes é desprezado. Segundo Hagen (1962) este comportamento de regurgitação do conteúdo sugado da presa é comum para os coccinelídeos, ocorrendo, assim, uma digestão pré-oral.

O consumo da presa pode durar muitos minutos consecutivos e durante este período os adultos permanecem parados em um mesmo local, no entanto, se molestados, tendem a se movimentar rapidamente, podendo carregar consigo sua presa ou não. Um mesmo predador, seja uma larva ou um adulto, pode se alimentar de mais de uma presa durante o dia, sendo a quantidade variável (Romero et al. 1974; Guerreiro, 2000; Silva et al., 2001). 
A quantidade de presas consumidas por estes insetos depende de inúmeros fatores, como temperatura, estação do ano, estágio de vida, tamanho da joaninha, e densidade de presa (Hagen, 1962; Hodek, 1967).

No entanto, de acordo com Hodek (1973) e Iperti (1999), o consumo de alimentos pelos coccinelídeos parece estar correlacionado, principalmente, com a temperatura e a densidade populacional da presa.

Dentro de um limite favorável de temperatura, as taxas de desenvolvimento e de consumo diário podem estar intrinsecamente ligadas (Santos \& Bueno, 1999). Em estudos com Pentilia egena, Guerreiro et al. (2003) observaram grande aumento no consumo de cochonilhas, quando houve o aumento da temperatura; o mesmo comportamento foi observado para Coccidophilus citricola por Silva (2002), e para Scymnus (Pullus) argentinicus (Weise) por Santos \& Bueno (1999).

Em estudos com Coccinella trifasciata Mulsant e C. califormica Mannerheim, Ives (1981) observou que houve aumento no consumo com o aumento da temperatura, e que este incremento foi transformado em maior quantidade de ovos, pois no mesmo período houve um aumento no número médio de oviposições. O mesmo comportamento foi observado por Guerreiro et al. (2001) para Pentilia egena e por Silva (2002) para C. citricola.

A densidade populacional da presa pode modificar a resposta dos inimigos naturais, quanto a predação, portanto influencia a relação predadorpresa existente. Segundo Salomon (1969) uma destas variações é baseada na resposta funcional do predador, que é o número de presas atacadas em função de sua densidade. De acordo com Tostowaryk (1972), os componentes da resposta funcional incluem a duração do tempo em que o predador e a presa ficam expostos um ao outro; a taxa de busca bem sucedida e o tempo de manuseio.

Estudando a resposta funcional de Scymnus (Pullus) argentinicus, às densidades variáveis de ninfas do pulgão Schizaphis graminum (Rondani), Vieira et al. (1997) verificaram que a taxa de consumo aumenta numa taxa 
decrescente em direção a um valor máximo, sendo segundo estes autores, uma tendência comum para estes predadores. Portanto, nas condições de campo o consumo será aumentado conforme o aumento da densidade da presa, o que implica em maior desenvolvimento do predador, influenciado por cópulas e oviposições mais freqüentes (Guerreiro, 1998; Guerreiro, 2000; Silva, 2002)

Outros fatores não tão importantes podem influenciar o consumo de presas, para as espécies de coccinelídeos, por exemplo, o estádio de vida em que o inseto se encontra. Segundo Iperti (1999) durante os diferentes estágios larvais, o consumo de presa aumenta exponencialmente, de acordo com o tamanho da larva. Somente no $4^{\circ}$ estádio as larvas são capazes de predar $80 \%$ do total das presas predadas durante todo o estágio larval (Hodek, 1973).

A época do ano pode influenciar o consumo de presa, segundo Iperti (1999) e Guerreiro et al. (2003), os coccinelídeos podem ter seu consumo aumentado em épocas próximas da estação da primavera, período de maior ocorrência de presas no campo, implicando em maior consumo e reprodução. Além disso, segundo Hodek \& Honek (1996), em épocas de reprodução, principalmente as fêmeas têm seu consumo aumentado, para a manutenção de suas exigências diárias, e para o fornecimento de fontes extras para a reprodução.

\subsection{Os coccinelídeos como predadores em agroecossistemas}

Para a implantação de programas de controle biológico e manejo integrado de pragas utilizando os coccinelídeos, ou qualquer outro inimigo natural, vários fatores devem ser considerados.

Hodek \& Honek (1996) observam que o modo de utilização e controle de pragas com coccinelídeos pode diferir com as diferentes zonas climáticas (contrastes entre zonas temperadas com tropicais e subtropicais), com a presa 
típica (cochonilhas, pulgões, ácaros, mosca branca etc.) e hábitat (jardins, bosques, pomares, culturas anuais e casa de vegetação) e, além disso, com a origem da espécie predadora, ou seja, se o inimigo natural é nativo ou introduzido.

Segundo Hodek (1973), o papel dos coccinelídeos no controle biológico de pragas foi demonstrado, nos surtos de pragas primárias ou secundárias, após tratamentos com inseticidas terem exterminado os inimigos naturais. A partir destas observações, é que os pesquisadores e agricultores começaram a notar a importância destes predadores nos mais variados agroecossistemas, pois sempre têm atuado no controle as pragas, mantendo-as num nivel abaixo daquele que poderia causar qualquer dano econômico às culturas.

Os coccinelídeos possuem todas as características necessárias para serem considerados bons predadores e terem sucesso no controle biológico de pragas agrícolas, ou seja, possuem capacidade de busca e apreensão de presas, alto grau de sincronia com a presa, alta razão de crescimento populacional e adaptação climática aos mais variados ambientes (Hagen, 1970; Hodek, 1973; Hodek e Honek, 1996).

Segundo Hodek \& Honek (1996) e Poppy (1997) para se conhecer a relação ou interação predador-presa de forma científica e prática, tem que ser realizado um completo estudo de campo sobre a dinâmica populacional de pragas e inimigos naturais, bem como determinar as razões de aumento ou diminuição de populações de insetos, as razões de predação e desenvolvimento em um determinado agroecossistema, e a observação do efeito da variação de fatores climáticos, que ocorre nas diferentes estações do ano (Iperti, 1999).

Mesmo sendo muito estudados e considerados bons controladores de pragas, pouco se sabe sobre a real efetividade destes predadores no campo, como controladores de pragas importantes. Segundo Frazer \& Raworth (1985), isto pode ser explicado, em parte, pela grande flutuação de suas presas durante 
um curto período de tempo, e conseqüentemente migração destes predadores para outras áreas que contenham seu alimento necessário.

A ocorrência de coccinelídeos em culturas agrícolas tem sido descrita em vários trabalhos (Putman, 1957; Putman, 1959; Santos et al. 1990; Parra et al. 2003). Os estudos e observações dos coccinelídeos no agroecossistema foram potencializados a partir da introdução da joaninha $R$. cardinalis e do grande sucesso no controle da cochonilha Icerya purchasi.

Estes inimigos naturais podem ser observados em ambientes considerados efêmeros, como as culturas anuais, ou em ambientes mais estáveis, como plantios florestais e pomares de frutiferas. Segundo Ehler \& Miller (1978) e Hall \& Ehler (1979) os maiores sucessos no controle biológico de pragas, utilizando coccinelídeos, são obtidos em sistemas agroflorestais e pomares, comparados com os plantios anuais. Segundo Wissinger (1997) a diferença entre estes ambientes é a estabilidade apresentada pelo hábitat, e estes predadores, parecem ser mais efetivos no controle de pragas em ambientes mais estáveis.

Em um agroecossistema florestal ou em um pomar, desde que bem manejados, as bases alimentares para os coccinelídeos podem ser mantidas, mesmo em épocas desfavoráveis à ocorrência de insetos no campo, como em épocas mais secas e frias do ano. O mesmo efeito não se observa para plantios anuais, que têm estes predadores presentes no campo durante uma determinada fase do ano, principalmente no início de desenvolvimento das culturas (Brown, 1993; Corbertt \& Rosenhein, 1996).

No entanto, alguns fatores podem influenciar a estabilidade e a manutenção destes insetos em ambientes efêmeros ou plantios anuais. Segundo Gravena (1983) e Campos et al. (1986), a ocorrência inicial de pulgões em culturas anuais (muitas vezes sendo pragas secundárias), pode influenciar no aumento da população de inimigos naturais, como os coccinelídeos, que permanecerão neste agroecossistema durante todo o 
período de desenvolvimento da cultura, alimentando-se não só de pulgões, mais de várias outras pragas importantes.

Guerreiro et al. (2001), estudando os coccinelídeos predadores que ocorrem na cultura do algodão, notaram que as várias espécies ocorreram em grandes quantidades no início da cultura, principalmente atraídos por pulgões, permanecendo na cultura durante o período de desenvolvimento, alimentandose de outros insetos, como fases jovens de Lepidoptera e Coleoptera. Resultados parecidos foram obtidos por Michelotto et al. (2003), quando estudaram vários cultivares de algodão.

De acordo com Hodek \& Honek (1996) as joaninhas surgem no início da ocorrência das pragas no campo, sendo que uma predação moderada, neste período, pode implicar em diminuição de chances de ocorrência de picos populacionais destas pragas.

Segundo Elliott et al. (2000) estes inimigos naturais são abundantes em campos de plantios de cereais, sendo, algumas vezes, efetivos no controle biológico de insetos pragas, e esta efetividade varia com a densidade populacional dessas pragas, e com outros fatores bióticos e abióticos. A temperatura, por exemplo, é importantíssima no aparecimento e desenvolvimento de coccinelídeos nesses campos de cereais.

Andrade et al. (2003) estudando a ocorrência de joaninhas na cultura do milho, observaram que para certas espécies, como $C$. sanguinea, o pico populacional foi obtido próximo do 'pendoamento' da cultura, ou seja, mais tardiamente. Segundo Hodek (1973); Hodek \& Honek (1996) e Iperti (1999) este comportamento pode ser atribuído ao fato da joaninha utilizar o pólen de algumas culturas como alimento alternativo, o que pode implicar em aumento da população no campo em questão, principalmente durante épocas reprodutivas da cultura. No entanto Guerreiro et al. (2001) relatam ser este comportamento mais comum para espécies polifagas, como $C$. sanguinea, pois estas possuem a capacidade de se desenvolver e reproduzir mesmo quando alimentadas com presas ou alimentos alternativos. 
Apesar de se ter um bom conhecimento sobre a preferência alimentar, condições climáticas e ambientais mais adequadas aos coccinelídeos, pouco se conhece sobre a ocorrência de coccinelídeos na maioria das plantas anuais e perenes cultivadas, principalmente no Brasil. Estes trabalhos parecem ser difíceis de serem realizados, principalmente pela falta de pesquisadores especialistas nos mais variados grupos de insetos dentro da família Coccinellidae, pois muitos destes insetos coletados por pesquisadores no Brasil, ainda não foram identificados.

Alguns estudos foram conduzidos em culturas anuais de importância econômica, como os realizados por Campos et al (1986), Guerreiro et al. (2001) e Michelotto et al. (2003), na cultura do algodão; Santos et al. (1990) e Andrade et al. (2003) na cultura do milho; Santos et al. (1990) na cultura da soja, no entanto estes estudos são poucos e, na maioria das vezes, não conclusivos.

\subsection{A importância dos coccinelídeos no agroecossistema citrícola}

A citricultura é, sem duvida, uma das culturas mais importantes no Brasil e no mundo. O valor monetário no mercado nacional e mundial atinge altas cifras. No entanto, é uma das culturas que apresenta certos fatores que podem se tornar limitantes se não forem bem manejados, como a ocorrência de pragas e os possiveis efeitos indesejáveis decorrentes da utilização de táticas de controle de pragas à fauna benéfica (Neves, 1992; Borges \& Almeida, 2000; Agrianual, 2002).

Nos pomares citricolas é possivel encontrar uma rica artropodofauna, sendo local de ocorrência de aranhas, ácaros, insetos pragas, predadores e parasitóides, pertencentes a diferentes táxons. Dentre estes, destacam-se como pragas do agroecossistema citrícola ácaros, moscas-das-frutas, cochonilhas, cigarrinhas, minadora-dos-citros e pulgões, que fazem parte do 
complexo de pragas primárias e secundárias dos citros (Nascimento et al., 1982; Gravena, 1984; Busoli, 1992; Paiva, 2000; Dantas, 2002 e Parra et al., 2003).

Os insetos pertencentes a ordem Hemiptera que é representada por várias espécies de cochonilhas e pulgões podem, em casos de surto populacional, causar sérios prejuízos ao agricultor por comprometer a produção de frutos.

As cochonilhas que ocorrem durante 0 ano no agroecossistema citrícola são insetos considerados pragas secundárias que vivem neste ambiente, muitas vezes, sem causar qualquer problema mais sério à cultura. No entanto, se qualquer desequilíbrio for ocasionado à esta cultura, como a utilização inadequada de defensivos agrícolas (Gravena \& Lara, 1976), efeitos adversos serão propiciados imediatamente na fauna benéfica deste agroecossistema (Dean et al., 1983; Gravena, 1990; Busoli, 1992). As cochonilhas de carapaça, em condições de desequilibrio ambiental, foram referidas por Campos et al. (1973) como uma das principais pragas dos pomares paulistas.

Entre as espécies que ocorrem nos citros, destacam as cochonilhas Selenaspidus articulatus Morgan; Parlatoria ziziphi (Lucas), Parlatoria pergandii Comstock; Parlatoria cinerea Deane \& Hadden; Chrysomphalus aonidum L. e Unaspis citri Comstock, que ocasionam danos diretos, como a sucção contínua de seiva, ou mesmo danos indiretos pela introdução de toxinas, que implicam no definhamento das plantas, com quedas de folhas e frutos, podendo chegar até a morte da planta (Bartra, 1974; Prates et al., 1985; Gravena 1986; Busoli, 1992; Pinto W.B.S., 1995 e Parra et al., 2003).

Dentre as espécies de predadores que atuam no controle de cochonilhas de carapaça, as joaninhas ocupam lugar de destaque, predando adultos, ninfas e ovos destas pragas (Mariconi, 1963 e Puzzi, 1966). Nas condições brasileiras, as joaninhas Pentilia egena (Moraes et al., 1995; Santos et al., 1992; Guerreiro, 1998; Guerreiro 2000; De Bortoli et al., 2001) e 
Coccidophilus citricola (Santos \& Gravena, 1991; Santos, 1995; Domenici, 1998 e Silva 2002), são as principais espécies predadoras de cochonilhas de carapaça que ocorrem nos citros, destacando-se pela grande freqüência de ocorrência durante todo o ano nos pomares, e o bom índice de predação apresentados.

Estas espécies de coccinelídeos são espécies que, por apresentarem importância destacada no controle de cochonilhas, têm sido estudadas e criadas em laboratórios, para a tentativa de realizar futuras liberações em campo (Santos, 1995; Guerreiro; 2000 e Silva 2002). No entanto, pouco se conhece sobre a flutuação populacional destas espécies predadoras durante o ano, a correlação de ocorrência destas espécies com as pragas no agroecossistema citrícola, bem como, a ocorrência em estratos na planta e sua relação com alimentos alternativos, conhecimentos que podem implicar no sucesso no controle de cochonilhas de carapaça e ocorrência destes predadores durante todo o ano, no agroecossistema citrícola.

Outra praga pertencente à ordem Hemiptera, que ataca os pomares citrícolas, é o pulgão conhecido vulgarmente como pulgão preto, Toxoptera citricida (Kirkaldy). O pulgão preto foi, provavelmente, introduzido no Brasil na década de 20, período que a citricultura estava em um bom momento, apresentando ótimo crescimento (Michaud, 1998).

O pulgão $T$. citricida ataca folhas, hastes, flores e brotos, causando danos diretos, como o enrolamento das folhas e redução do desenvolvimento de plantas, e danos indiretos, como agente vetor de vírus causador da 'tristeza dos citros' (Michaud, 1999a).

Segundo Michaud (1999b) e Michaud (2000) o pulgão T. citricida é uma praga importante para o agroecossistema citrícola no mundo. O primeiro impacto econômico provocado na citricultura, por esta praga, tratou-se dos problemas decorridos da transmissão vírus, causador de importante doença em citros. $T$. citricida tem grande eficiência na transmissão do vírus da 'tristeza dos 
citros', doença que causa o declínio rápido da planta, seca dos galhos, podridão das radicelas, podendo na maioria das vezes, causar a morte da planta.

Os problemas ocasionados pela 'tristeza dos citros' no Brasil foram documentados por Moreira (1942) e Meneghini (1946). Neste período já se suspeitava que a doença era causada por um vírus, transmitido por um pulgão, que na época era chamado de Aphis tavaresi.

Após a observação da 'tristeza dos citros', e decorrentes problemas associados a esta doença para a citricultura, a formação de mudas no Brasil foi inteiramente modificada. Todas as plantas de laranja doce deixaram de ser enxertadas em laranja azeda, pois segundo Meneghini (1946), os portaenxertos de laranja azeda eram suscetíveis à 'tristeza dos citros', para serem enxertadas em limão cravo, que segundo Müller (1980) conferia a planta citrícola maior tolerância ao vírus, visto que os pulgões da espécie $T$. citricida eram constantes no agroecossistema, e dificilmente seriam exterminados dos campos citrícolas do Brasil.

Apesar da diminuição dos problemas decorrentes da ocorrência da tristeza dos citros nos pomares citrícolas relativos à década de 40 do século 20 , principalmente, devido à utilização do limão cravo como porta enxerto. Os problemas com a transmissão de agentes causadores de doença, pelo pulgão, parecem não ter terminado. Atualmente, tem surgido um novo problema para a citricultura brasileira, uma doença chamada de 'morte súbita dos citros', que tem sido comparada com a tristeza dos citros, pois os efeitos ocasionados são semelhantes aos causados por esta doença, e tem, também, como possível transmissor, o pulgão preto Toxoptera citricida (Gravena, 2003).

Observando, então, a grande importância desta praga no agroecossistema citrícola, vários pesquisadores têm trabalhado no sentido de determinar a flutuação deste inseto e de seus possíveis inimigos naturas, incluindo as espécies de coccinelídeos. Segundo Oliveira (1976) o controle integrado do pulgão preto terá maior eficiência se houver maior conhecimentos 
sobre a flutuação desta praga e seus inimigos naturais, no decorrer do ano agrícola.

Lara et al. (1977) observaram os efeitos de fatores climáticos na ocorrência de $T$. citricida em citros, e notaram que não houve correlação entre estes fatores e a ocorrência do pulgão; segundo os autores, o pico de ocorrência deste inseto foi relacionado com o desenvolvimento vegetativo das plantas de citros.

De acordo com Michaud (1998), por se alimentar de seiva de regiões terminais da planta de citros, como brotações, folhas novas e flores, sendo relacionados com danos primários (enrolamento de folhas e definhamento destas regiões novas) e secundários como a transmissão de vírus, o pulgão preto dos citros inicia seu aparecimento na cultura poucas semanas após o inicio das chuvas, as quais induzem o crescimento de partes novas. Apesar da importância da chuva para o início das brotações, Michaud (1999a) comenta sobre o controle natural destes insetos, principalmente em épocas de intensas chuvas, fenômeno que contribui para a diminuição da população em campo, e da migração para outras áreas.

Dentre os inimigos naturais do pulgão preto, os coccinelideos são vistos como um dos mais importantes, seja pela sua ocorrência constante no pomar ou por apresentar estreita ligação com sua presa.

Em nivel mundial, várias espécies foram relacionadas como predadoras do pulgão preto na cultura dos citros, dentre as quais, Chilocorus cacti (L.), Cladis nitidula (F.), Coccinella septempunctata, Coleomegilla maculata (Degeer), Coleophora inaequalis (F.), Coleomegilla innotata (Mulsant), Cycloneda sanguinea, Diomus sp., Egius platycephalus Mulsant, Hippodamia convergens (Guerin), Hyperaspis sp., Nephapis sp., Olla v-nigrum (Mulsant), Procula ferruginea (Oliver), Scymnus floralis (F.) e Scymnus sp. destacam-se como as mais importantes, pois são coccinelídeos que têm como presa essencial o pulgão T. citricida (Lara et al., 1977; Chagas et al., 1982; Michaud, 1998). 
Segundo Michaud (1998) de todas as espécies observadas, a joaninha $C$. sanguinea foi a que teve maior ocorrência, sendo a espécie mais importante no controle do pulgão preto em vários paises da América Latina.

No Brasil, C. sanguinea foi observada por Lara et al. (1977) em levantamentos de espécies predadoras de ocorrência no agroecossistema citrícola, sendo esta espécie de ocorrência constante e apresentando grande eficiência no controle do pulgão preto. No entanto, de acordo com o trabalho realizado por Chagas et al. (1982), C. sanguinea, apesar de estar presente nos levantamentos, foi encontrada em baixa quantidade, ao contrário de Scymnus sp., que foi a espécie mais abundante e relacionada com o pulgão $T$. citricida.

Além das espécies descritas anteriormente, outros coccinelídeos como Diomus sp., Delphastus sp., Hyperaspis sp., Azya luteipes e Stethorius sp., foram relatados como importantes predadores do pulgão preto principalmente, devido sua intima relação com a praga e freqüência de ocorrência no agroecossistema citrícola brasileiro (Gravena, 1978; Gravena \& Fornasieri, 1979; Santos et al., 1990 e Parra et al. 2003).

Apesar da existência de vários trabalhos que visaram os estudos das pragas dos citros e seus principais inimigos naturais como os coccinelídeos, mais pesquisas nessa área são requeridas, devido ao surgimento de novos problemas de doenças e pragas e o pouco conhecimento da relação destes insetos com seus principais inimigos naturais. 
3 OCORRÊNCIA ESTACIONAL DE Coccidophilus citricola BRĖTHES, 1905 (COLEOPTERA: COCCINELLIDAE) E DE SUAS PRINCIPAIS PRESAS NA CULTURA DOS CITROS

\section{Resumo}

Este trabalho trata da ocorrência estacional, constância de Coccidophilus citricola e a correlação entre sua ocorrência e as cochonilhas de carapaça que ocorrem nos citros. O estudo foi desenvolvido em um pomar de citros, no municipio de Taiúva, SP, durante o periodo de março/2002 a fevereiro/2003. As amostragens foram realizadas quinzenalmente em 25 plantas ao acaso, através de observações da presença de C. citricola, no estrato superior da planta (folhas e ramos) e no estrato inferior (troncos e pernadas), em um caminhamento ao redor de cada planta. Em cada planta amostrada retirou-se folhas do estrato superior, e uma pequena porção $\left(1 \mathrm{~cm}^{2}\right)$ da casca, do estrato inferior, para que fosse observada a ocorrência concomitante de cochonilhas de carapaça. A amostragem foi eficiente, observando-se que $C$. citricola tem ocorrência semelhante nos estratos inferior e superior da planta, sendo mais abundante em meado da primavera e início do verão. C. citricola mostrou ser uma espécie constante no pomar citricola, tendo sua ocorrência correlacionada positiva e significativamente com as cochonilhas Parlatoria ziziphi e $P$. cinerea, pragas importantes da cultura dos citros. 
SEASONAL OCCURRENCE OF Coccidophilus citricola BRÈTHES, 1905 (COLEOPTERA: COCCINELLIDAE) AND ITS SCALE PREYS IN THE CITRUS CROP

Summary

This paper deals with the seasonal occurrence of Coccidophilus citricola and the correlations of its occurrence with that of the citrus pest scales. The experiments were set in a citrus crop, in the municipality of Taiúva, State of São Paulo, Brazil, during the period from March/2002 to February/2003. The samplings were fortnightly taken from 25 plants by observing the occurrence of C. citricola in the plant upper stratum (leaves and twigs) and the inferior stratum (trunk) walking around each plant. The results have indicated that C. citricola occurs in both strata, either upper of inferior, being more abundant in mid spring and in the beginning of summer. It was also observed that its occurrence is positively and significantly correlated with that of the scales Parlatoria ziziphi and $P$. cinerea, important pests of citrus crops. 


\subsection{Introdução}

O Brasil ocupa a primeira posição mundial na produção de citros, sendo responsável por $25 \%$ da produção mundial de frutas frescas e $50 \%$ da produção de suco de laranja concentrado (Borges \& Almeida, 2000). É um setor que ocupa lugar de destaque na economia brasileira, gerando divisas e, principalmente, renda interna, emprego e contribuição em termos nutricionais (Neves, 1992; Agrianual, 2002).

O agroecossistema citricola apresenta uma rica artropodofauna, abrigando grande quantidade de ácaros, insetos fitófagos, predadores e parasitóides, pertencentes a diferentes grupos taxonômicos (Nascimento et al., 1982). Entre as pragas destacam-se ácaros, cochonilhas, moscas-das-frutas, bicho-furão, besouro de raízes, cigarrinhas, e minadora-dos-citros (Gravena, 1984; Busoli, 1992; Paiva, 2000; Dantas, 2002).

A ocorrência de desequilíbrio ambiental causado pela aplicação intensiva de agrotóxicos não seletivos, tem sido, há muito tempo, observada em várias culturas destacando-se, dentre estas, a cultura dos citros (Gravena \& Lara, 1976). Com a finalidade de preservar seus pomares contra as pragas primárias, os produtores rurais utilizam agrotóxicos, na maioria das vezes não seletivos, que propiciam efeitos adversos sobre a fauna benéfica, causando aumento populacional de pragas secundárias em detrimento da redução populacional de seus inimigos naturais (Dean et al., 1983; Gravena, 1990; Busoli, 1992).

As cochonilhas que ocorrem no agroecossistema citricola são pragas secundárias que podem atingir o 'status' de pragas importantes, de acordo com o desequilibrio ambiental ocorrido. Dentre estas se destacam as cochonilhas Selenaspidus articulatus Morgan; Parlatoria ziziphi (Lucas), Parlatoria pergandii Comstock; Parlatoria cinerea Deane \& Hadden; Chrysomphalus aonidum L. e Unaspis citri Comstock (Gravena 1986; Busoli 1992; Pinto W. B.S., 1995) 
Segundo Pinto W.B.S. (1995), as cochonilhas quando em surtos populacionais, causam danos que podem ser severos, pois além de realizarem a sucção contínua de seiva de folhas, frutos e ramos, introduzem toxinas que causam o depauperamento da planta, implicando na queda de folhas e depreciação da qualidade dos frutos.

Uma das alternativas ao uso contínuo de agrotóxicos, que tem implicado no aumento da população de pragas secundárias, como as cochonilhas, é o aumento e conservação de predadores e parasitóides nos pomares citrícolas (De Bach, 1964; Hodek, 1973). Os predadores atuam de forma enfática no controle biológico de cochonilhas, diminuindo os danos causados por esta praga no agroecossistema citrícola (Silva, et al., 2003).

Dentre os predadores presentes no agroecossistema citrícola, os pertencentes à família Coccinellidae se destacam devido a sua atuação na redução de populações de importantes pragas agrícolas como afídeos, cochonilhas e ácaros (Hagen, 1962; Puzzi, 1966 e Parra et al., 2003). Segundo Olkowski et al. (1990), os insetos pertencentes à esta família estão distribuídos pelo mundo e compreendem cerca de 5000 espécies conhecidas, sendo cosmopolitas e presentes em quase todos os ecossistemas, como florestas, cerrados, tundras, culturas agrícolas etc. Adaptadas às mais variadas condições ambientais apresentando comportamento diferente de acordo com o nicho ecológico ocupado (Iperti, 1999).

Na América do Sul e no Brasil, a joaninha Coccidophilus citricola Brèthes destaca se como uma das mais importantes predadoras de cochonilhas de carapaça dos citros (Gravena, 1980; Santos, 1995; Silva et al., 2003). Observações realizadas por Prates et al. (1985) e Leão Neto et al. (1986), referiram ser a joaninha $C$. citricola importante predadora de cochonilhas de carapaça que ocorrem nos citros. No entanto, segundo Silva (2002), poucos estudos a respeito de sua bioecologia são encontrados, devido a seu tamanho diminuto e dificuldades na criação em laboratórios. 
Considerando a existência de poucas referências, principalmente no que diz respeito a estudos realizados em campo, envolvendo $C$. citricola, o presente trabalho teve como objetivo determinar a ocorrência estacional desta espécie, o estrato da planta ocupado, bem como a correlação de ocorrência com suas principais presas.

\subsection{Material e Métodos}

O experimento foi conduzido num pomar comercial de citros Citrus sinensis (L.) variedade 'Pêra-Rio', em Taiúva, SP, constando de um talhão de 2000 plantas, com 4 anos de idade. Foram realizadas amostragens quinzenais, durante as quatro estações no período de março/2002 a fevereiro/2003. Em cada amostragem avaliou-se 25 plantas ao acaso, durante aproximadamente 5 minutos por planta, seguindo a metodologia descrita por Iperti (1999) e Lo (2000), que se baseia na amostragem visual de coccinelídeos, durante um período mínimo de observação.

A amostragem foi realizada através do caminhamento ao redor da planta, sendo durante este processo, observada a presença de larvas e adultos de C. citricola nas folhas e ramos (estrato superior da planta) e troncos e pernadas (estrato inferior da planta). Os coccinelídeos foram identificados através de comparações com materiais identificados mantidos pelo Departamento de Fitossanidade, FCAV, UNESP/Jaboticabal.

Além da observação e coleta de $C$. citricola, procurou-se realizar a amostragem, concomitante, das principais pragas associadas à presença ou não deste predador na área estudada. Para tanto, do estrato superior de cada planta, coletou-se cinco folhas, ao acaso, sendo estas retiradas de regiões da planta que correspondiam com a altura do peito do coletor, aproximadamente 1,50 metros, pois segundo Pinto A.S. (1995), é esta região da planta, uma das 
mais representativas quanto a ocorrência de cochonilhas de carapaça, como as cochonilhas $S$. articulatus e $P$. ziziphi. No estrato inferior de cada planta, foi retirada, com o auxílio de canivete, uma porção de, aproximadamente, $1 \mathrm{~cm}^{2} \mathrm{da}$ região superficial da casca de troncos e pernadas, para a contagem do número de cochonilhas $P$. cinerea.

O material coletado foi acondicionado em sacos plásticos encaminhados para o laboratório, onde com auxílio de estereoscópio, pincéis e agulhas histológicas, procedeu-se a contagem do número de cochonilhas vivas (confirmação realizada através do levantamento das carapaças das cochonilhas), e identificação das espécies coletadas, através de comparações com materiais identificados e mantidos pelo Departamento de Fitossanidade FCAV/ UNESP - Jaboticabal.

De posse dos dados registrados, determinou-se, através de análise de variância e teste de comparação de médias (Tukey a $5 \%$ ), o local na planta preferido para ocorrência de $C$. citricola, além da realização de testes de correlações lineares simples, entre o número médio de $C$. citricola por unidade amostral e das principais cochonilhas observadas, determinando a abundância deste coccinelídeo nas diferentes épocas ou estações do ano.

Com o estudo da porcentagem de ocorrência de C. citricola nos levantamentos, foi calculada a constância de ocorrência das espécies estudadas, através da fórmula descrita por Silveira Neto et al. (1976):

$$
C=\frac{p x 100}{N}
$$

Onde: $\mathrm{C}=$ constância de ocorrência

$\mathrm{p}=$ número de amostragens contendo a espécie estudada

$\mathrm{N}=$ total de amostragens efetuadas 


\subsection{Resultados e Discussão}

O tipo de amostragem utilizada demonstrou grande eficiência. Em todas as amostragens $C$. citricola foi observada, contada, e, alguns exemplares foram coletados, concordando com Iperti (1999) e Lo (2000), que descreveram ser o método visual o mais adequado para a contagem de coccinelídeos em frutiferas, como as plantas de citros.

No entanto, este método de amostragem não permitiu a visualização de oviposiçōes, pois segundo Silva (2002) e Guerreiro et al. (2003), os coccinelídeos predadores de espécies de cochonilhas de carapaça ovipositam sob as carapaças de cochonilhas predadas. Comportamento que pode ser, provavelmente, atribuído a proteção da prole quanto a predação, parasitismo e condições climáticas desfavoráveis (Guerreiro, 2001).

Na maioria das amostragens efetuadas, observou-se a presença de $C$. citricola no estrato superior e no estrato inferior da planta, não havendo diferença estatística entre a ocorrência desta joaninha nos dois estratos estudados, quando comparadas às médias totais do número de coccinelídeos, em todas as amostragens (Tabela 1). Estes resultados indicam que C. citricola não apresentou preferência pelas presas presentes em cada estrato, concordando com Hagen (1962), Hodek (1973) e Hodek \& Honek, (1996), os coccinelídeos apresentam uma dinâmica de caminhamento na planta, sempre em busca de presas mais abundantes e, segundo Silva (2002) de fases de desenvolvimento mais preferidas, como ninfas móveis ou recém-fixadas.

Com os resultados, Tabela 1 , nota-se que o pico de ocorrência de $C$. citricola no estrato superior ocorreu no início de janeiro de 2003, com uma média de 11,32 $\pm 1,43$ joaninhas amostradas por planta, representando $77,53 \%$ do total de individuos desta espécie observado neste período, quando comparados os dois estratos estudados, diferenciando-se do observado para o estrato inferior, que foi obtido no início de novembro de 2002 , com $8,80 \pm 1,87$ 
joaninhas amostradas, o que foi representado por $88,35 \%$ do total de $C$. citricola observado (Tabela 1).

Tabela 1. Número médio e porcentagem de ocorrência de $C$. citricola/planta, nas diferentes estações do ano, no estrato superior (folhas e ramos), e inferior (troncos e pernadas). Taiúva, SP, 2002/2003

\begin{tabular}{|c|c|c|c|c|c|c|c|}
\hline \multirow{2}{*}{$\begin{array}{c}\text { Datas de } \\
\text { Amostragem }\end{array}$} & \multirow{2}{*}{$\begin{array}{c}\text { Estação } \\
\text { do ano }\end{array}$} & \multicolumn{2}{|c|}{ C. citricola /planta * } & \multicolumn{2}{|c|}{ \% de ocorrência } & \multicolumn{2}{|c|}{ Total/amostragem } \\
\hline & & Superior & Inferior & Superior & Inferior & Superior & Inferior \\
\hline 07/03/02 & Verão & $0,20 \pm 0,08$ & $0,08 \pm 0,08$ & 71,43 & 28,57 & 5 & 2 \\
\hline $14 / 03 / 02$ & Verão & $0,28 \pm 0,11$ & $0,64 \pm 0,32$ & 30,43 & 69,57 & 7 & 16 \\
\hline 27/03/02 & Outono & $0,52 \pm 0,22$ & $0,64 \pm 0,28$ & 44,83 & 55,17 & 13 & 16 \\
\hline $11 / 04 / 02$ & Outono & $0,16 \pm 0,08$ & $0,28 \pm 0,14$ & 36,36 & 63,64 & 4 & 7 \\
\hline $25 / 04 / 02$ & Outono & $0,12 \pm 0,07$ & $0,12 \pm 0,12$ & 50,00 & 50,00 & 3 & 3 \\
\hline $08 / 05 / 02$ & Outono & $0,08 \pm 0,08$ & $0,60 \pm 0,34$ & 11,76 & 88,24 & 2 & 15 \\
\hline $23 / 05 / 02$ & Outono & $0,16 \pm 0,09$ & $0,32 \pm 0,18$ & 33,33 & 66,67 & 4 & 8 \\
\hline $12 / 06 / 02$ & Outono & 0 & 0 & 0 & 0 & 0 & 0 \\
\hline $27 / 06 / 02$ & Inverno & 0 & $0,12 \pm 0,12$ & 0 & 100,00 & 0 & 3 \\
\hline 04/07/02 & Inverno & 0 & $0,12 \pm 0,09$ & 0 & 100,00 & 0 & 3 \\
\hline 19/07/02 & Inverno & $0,12 \pm 0,12$ & $0,68 \pm 0,30$ & 15,00 & 85,00 & 3 & 17 \\
\hline 07/08/02 & Inverno & $0,04 \pm 0,04$ & $0,60 \pm 0,28$ & 6,25 & 93,75 & 1 & 15 \\
\hline $16 / 08 / 02$ & Inverno & 0 & $0,28 \pm 0,16$ & 0 & 100,00 & 0 & 7 \\
\hline $06 / 09 / 02$ & Inverno & 0 & $0,44 \pm 0,25$ & 0 & 100,00 & 0 & 11 \\
\hline $12 / 09 / 02$ & Inverno & $0,40 \pm 0,20$ & $0,44 \pm 0,15$ & 47,62 & 52,38 & 10 & 11 \\
\hline $03 / 10 / 02$ & Primavera & $0,40 \pm 0,18$ & $0,84 \pm 0,48$ & 32,26 & 67,74 & 10 & 21 \\
\hline $12 / 10 / 02$ & Primavera & $0,16 \pm 0,12$ & $0,80 \pm 0,31$ & 16,67 & 83,33 & 4 & 20 \\
\hline $27 / 10 / 02$ & Primavera & $1,52 \pm 0,34$ & $1,32 \pm 0,57$ & 53,52 & 46,48 & 38 & 33 \\
\hline 07/11/02 & Primavera & $1,04 \pm 0,30$ & $8,80 \pm 1,87$ & 10,44 & 88,35 & 26 & 220 \\
\hline 21/11/02 & Primavera & $3,52 \pm 0,99$ & $3,24 \pm 0,60$ & 52,07 & 47,93 & 88 & 81 \\
\hline $05 / 12 / 02$ & Primavera & $4,12 \pm 0,98$ & $3,40 \pm 0,50$ & 54,79 & 45,21 & 103 & 85 \\
\hline 19/12/02 & Primavera & $5,64 \pm 0,97$ & $6,28 \pm 1,54$ & 47,32 & 52,68 & 141 & 157 \\
\hline 09/01/03 & Verão & $11,32 \pm 1,43$ & $3,28 \pm 0,46$ & 77,53 & 22,47 & 283 & 82 \\
\hline $31 / 01 / 03$ & Verão & $3,88 \pm 0,76$ & $1,68 \pm 0,35$ & 69,78 & 30,22 & 97 & 42 \\
\hline $14 / 02 / 03$ & Verão & $1,08 \pm 0,33$ & $1,16 \pm 0,72$ & 48,21 & 51,79 & 28 & 29 \\
\hline 27/02/03 & Verão & $1,96 \pm 0,42$ & $0,68 \pm 0,26$ & 74,24 & 25,76 & 49 & 17 \\
\hline TOTAL $^{* *}$ & & $1,41 \pm 0,50 A$ & $1,42 \pm 0,41 \mathrm{~A}$ & 49,95 & 50,05 & 919 & 921 \\
\hline
\end{tabular}


No entanto, ambos os picos populacionais ocorreram nos meses de maior abundância da espécie no campo, que, de acordo com os resultados, Figura 1, ocorreu da amostragem realizada no início de novembro de 2002 ao final de janeiro de 2003, período que corresponde com meado da primavera e início do verão. Concordando com Hagen (1962), Hagen (1970) e Iperti (1999), é este período o de maior ocorrência de coccinelídeos em campo, principalmente, devido à presença abundante de presas para a alimentação, que implica em melhor desenvolvimento, aumento de cópulas, deposição de ovos e conseqüente aumento da população no campo.

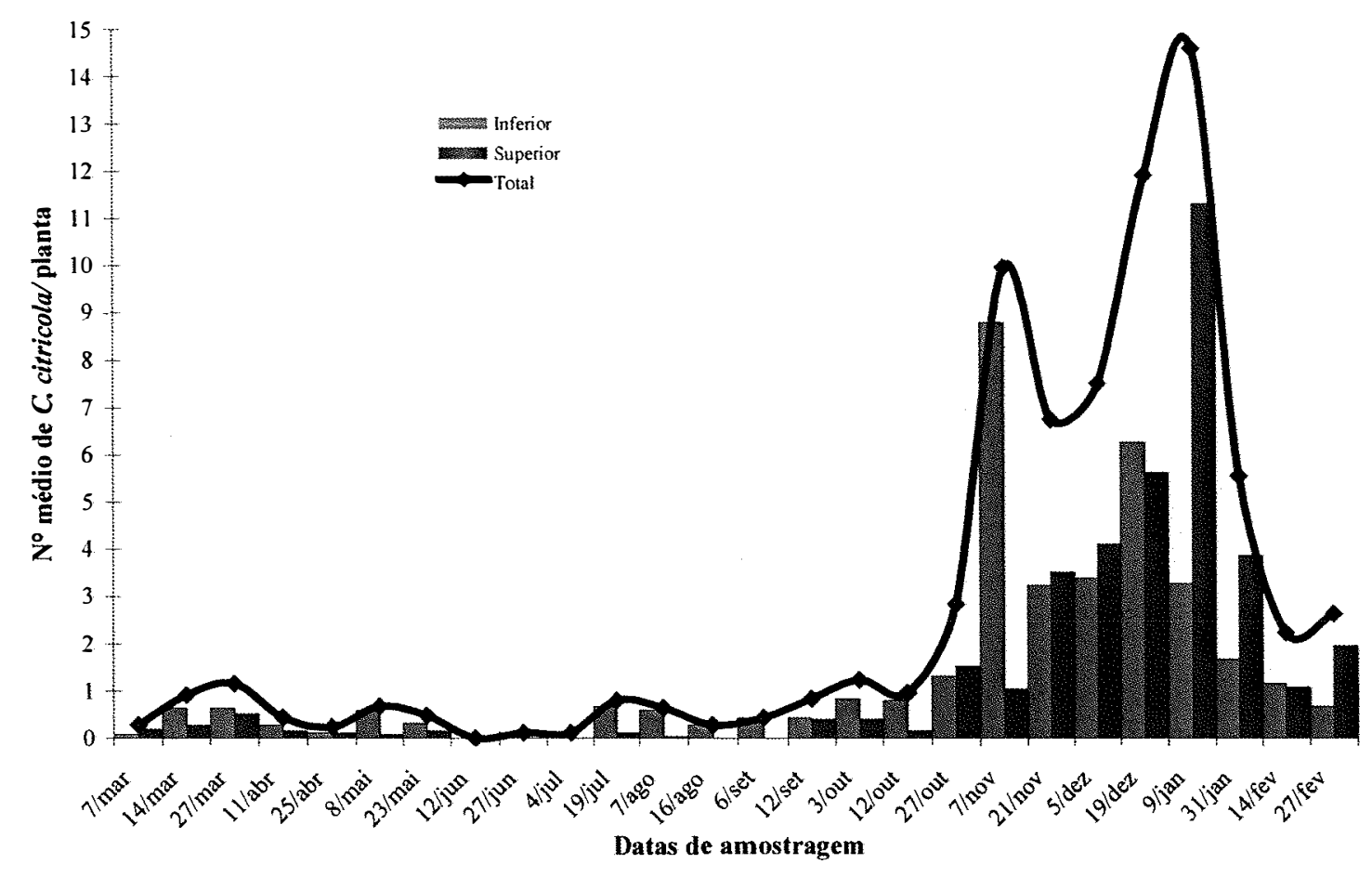

Figura 1 - Ocorrência estacional de C. citricola no estrato inferior (troncos e pernadas) e superior (folhas e ramos) da planta de citros, durante 0 período de março/2002 a fevereiro/2003. Taiúva - SP

Os indivíduos adultos da espécie C. citricola (Figura 2A) tiveram maior ocorrência no agroecossistema citrícola, no período de estudo. Insetos na fase larval (Figura 2B), praticamente não foram observados durante todas as amostragens tendo sua ocorrência aumentada em meados da primavera e 
início do verão, período, como descrito anteriormente, que tem o aumento do número de presas e conseqüente aumento da população de fases não migrantes do predador, como a fase larval (Silveira Neto et al. 1976; Guerreiro et al., 2003) (Figura 3).
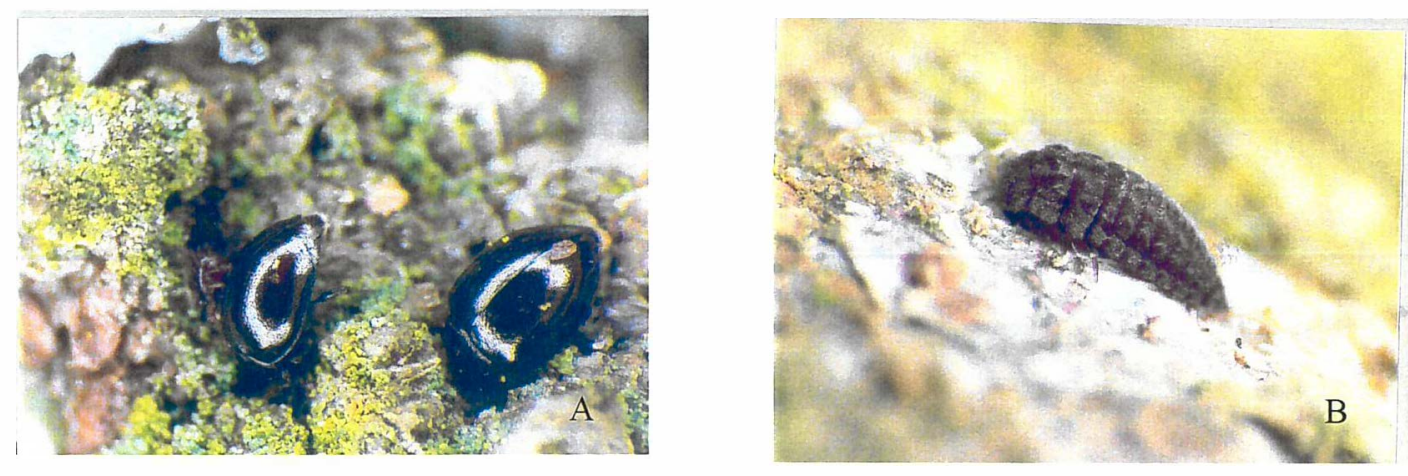

Figura 2 - Aspectos de adultos (A) e larva (B) da espécie C. citricola. (Fotografias: Heraldo Negri)

De acordo com Silveira Neto et al. (1976), determinou-se a constância de ocorrência de C. citricola durante 0 ano, obtendo-se $80,76 \%$ de constância no estrato superior e $96,15 \%$ no estrato inferior da planta; de acordo com estes resultados, pode se concluir que a espécie $C$. citricola é uma espécie constante na cultura dos citros.

De modo geral, sem considerar o estrato da planta ou a fase de desenvolvimento de $C$. citricola, nota-se (Tabela 1 e Figura 1) que 0 coccinelídeo esteve presente em, praticamente, todas as amostragens, mesmo em períodos na estação do inverno. Concordando com Hall \& Ehler (1979) e Wissinger (1997), culturas perenes como o citros são hábitats preferidos por coccinelídeos, devido à maior estabilidade e opções quanto à alimentação e abrigo, mesmo em épocas desfavoráveis.

As principais cochonilhas de carapaça observadas no período de março/2002 a fevereiro/2003, na parte aérea da planta (folhas), foram as cochonilhas Parlatoria ziziphi (Figura 4A) e Selenaspidus articulatus (Tabela 2), 
sendo a primeira espécie mais abundante, em todo o período, com uma média de 2,35 $\pm 0,46$ cochonilhas por folha em cada amostragem. Já a cochonilha $S$. articulatus ocorreu em baixo número, comparada com $P$. ziziphi, sendo observada uma média de 0,20 \pm 0,34 cochonilhas por folha em cada amostragem. A maior abundância de $P$. ziziphi na área foi observada nas amostragens realizadas no período da primavera de 2002, com um pico de ocorrência de 9,648 $\pm 2,28$ cochonilhas por folha (Figura 5).

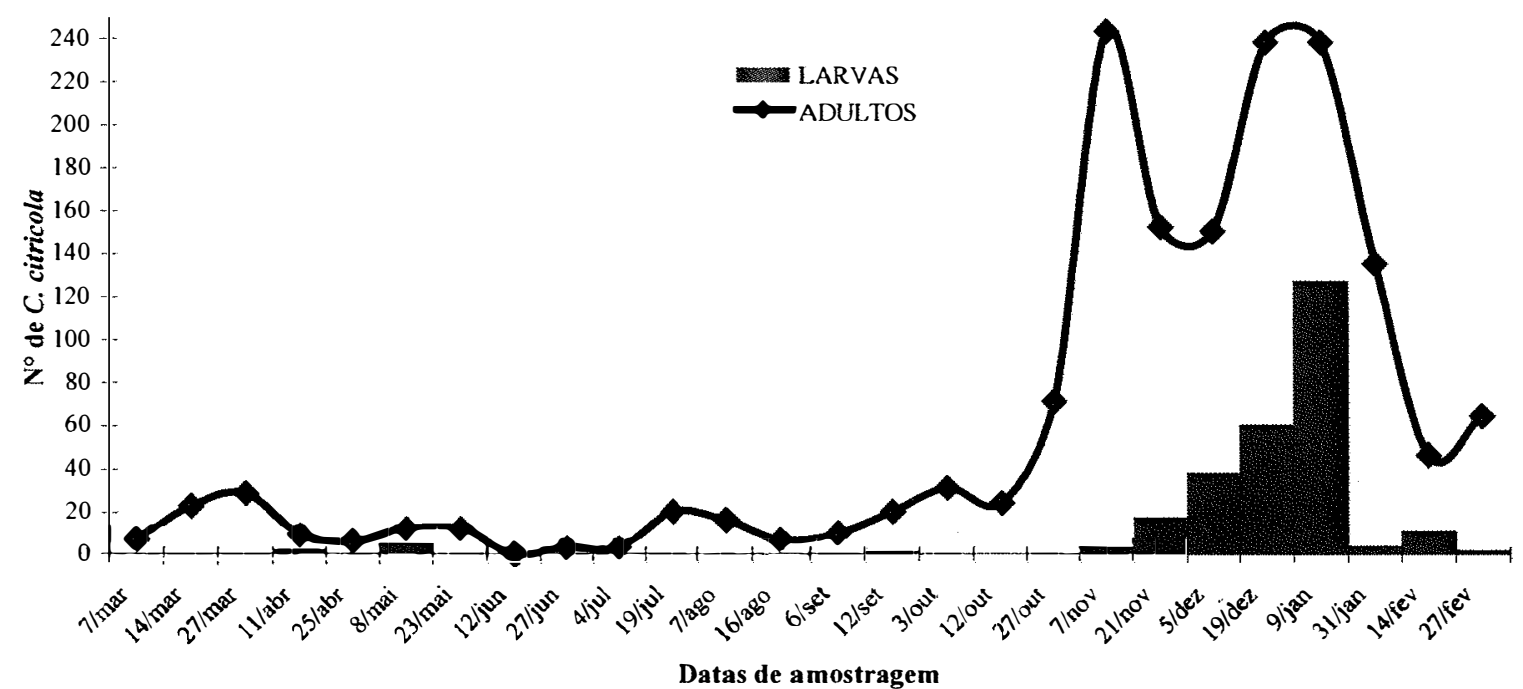

Figura 3 - Ocorrência estacional de larvas e adultos de C. citricola na planta de citros, durante o período de março/2002 a fevereiro/2003. Taiúva SP

Os resultados de ocorrência da cochonilha na parte aérea da planta, descritos anteriormente, corroboram com os resultados obtidos por Pinto A.S. (1995) e Pinto W.B.S. (1995), que observaram maiores ocorrências das cochonilhas na parte aérea em períodos quentes e úmidos do ano.

De acordo com os resultados, Figura 5 , nota-se que a ocorrência de C. citricola no estrato superior da planta é concomitante com o período de maior ocorrência das cochonilhas da parte aérea $P$. ziziphi e $S$. articulatus. A presença deste predador no campo foi correlacionada com a presença da 
cochonilha $P$. ziziphi, observando-se correlação linear, positiva e significativa $(r=0,52 ; t=2,89 ; p=0,01)$, o que implicou em aumento do predador com 0 aumento de sua presa.
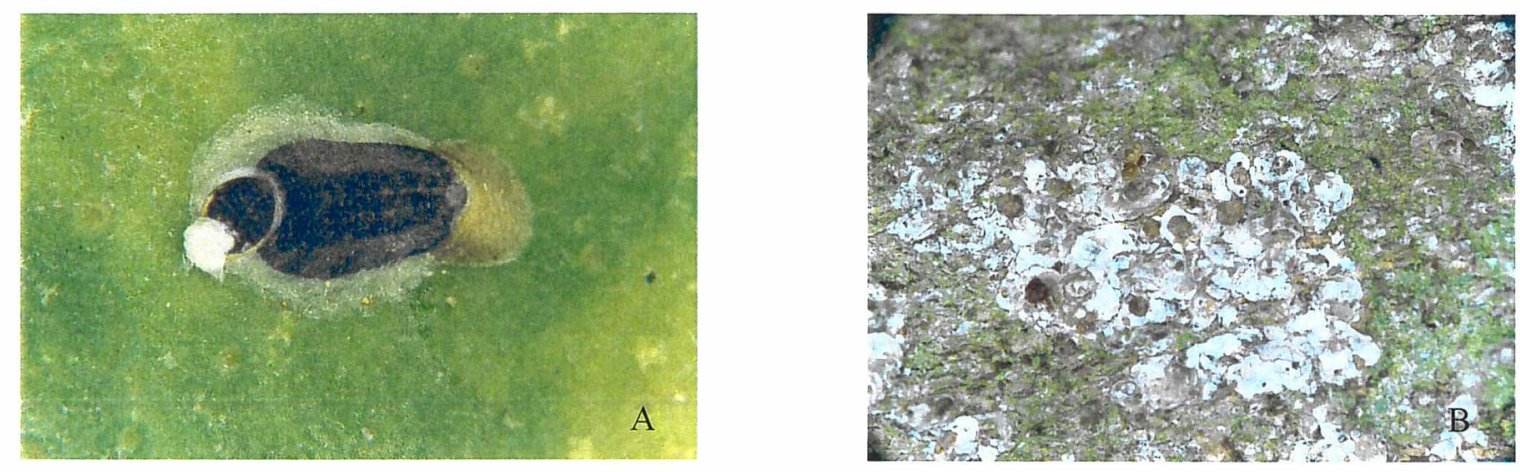

Figura 4 - Aspecto da cochonilha P. ziziphi (A) e da cochonilha P. cinerea (B). (Fotografia: Heraldo Negri)

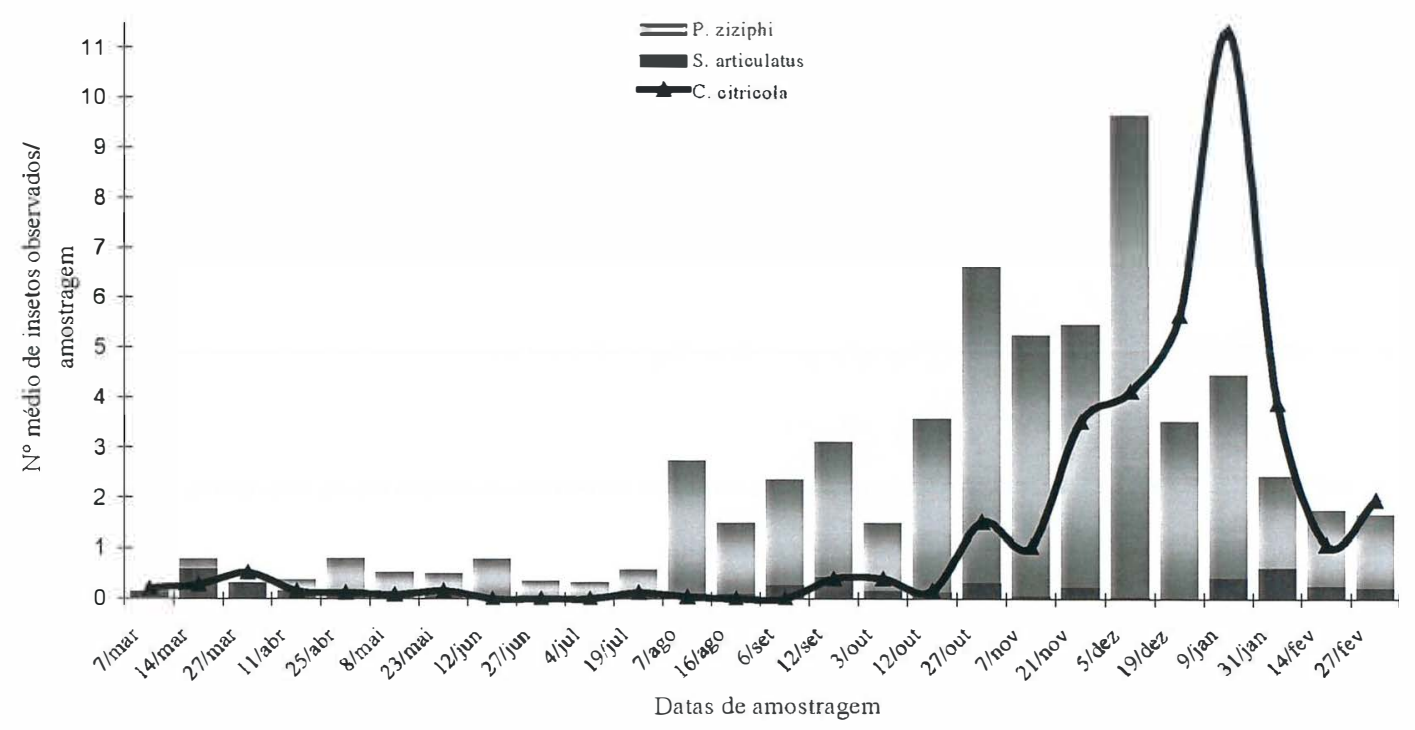

Figura 5 - Ocorrência estacional de $C$. citricola e suas principais presas $P$. ziziphi e $S$. articulatus (observadas no estrato superior da planta), durante período de março/2002 a fevereiro/2003. Taiúva - SP 
Tabela 2. Número médio das cochonilhas Parlatoria ziziphi, Selenaspidus articulatus e Parlatoria cinerea observadas nas diferentes estações do ano. Taiúva, SP, 2002/2003

\begin{tabular}{|c|c|c|c|c|}
\hline AMOSTRAGENS & $\begin{array}{l}\text { Estação do } \\
\text { ano }\end{array}$ & Parlatoria ziziphi* & $\begin{array}{l}\text { Selenaspidus } \\
\text { articulatus* }\end{array}$ & $\begin{array}{l}\text { Parlatoria } \\
\text { cinerea* }\end{array}$ \\
\hline 07/03/02 & Verão & $0,128 \pm 0,04$ & $0,136 \pm 0,01$ & $0,080 \pm 0,08$ \\
\hline $14 / 03 / 02$ & Verão & $0,792 \pm 0,24$ & $0,600 \pm 0,12$ & $1,080 \pm 0,57$ \\
\hline 27/03/02 & Outono & $0,248 \pm 0,08$ & $0,328 \pm 0,10$ & $0,240 \pm 0,14$ \\
\hline $11 / 04 / 02$ & Outono & $0,384 \pm 0,14$ & $0,160 \pm 0,04$ & $0,320 \pm 0,15$ \\
\hline $25 / 04 / 02$ & Outono & $0,808 \pm 0,30$ & $0,184 \pm 0,05$ & $0,240 \pm 0,14$ \\
\hline $08 / 05 / 02$ & Outono & $0,528 \pm 0,11$ & $0,100 \pm 0,04$ & $0,480 \pm 0,23$ \\
\hline $23 / 05 / 02$ & Outono & $0,512 \pm 0,19$ & $0,064 \pm 0,03$ & $0,280 \pm 0,18$ \\
\hline $12 / 06 / 02$ & Outono & $0,800 \pm 0,18$ & $0,007 \pm 0,04$ & $0,160 \pm 0,09$ \\
\hline $27 / 06 / 02$ & Invemo & $0,360 \pm 0,10$ & $0,024 \pm 0,01$ & 0 \\
\hline $04 / 07 / 02$ & Invemo & $0,336 \pm 0,09$ & $0,016 \pm 0,01$ & $0,56 \pm 0,32$ \\
\hline $19 / 07 / 02$ & Invemo & $0,576 \pm 0,23$ & $0,112 \pm 0,04$ & $0,760 \pm 0,30$ \\
\hline 07/08/02 & Invemo & $2,736 \pm 0,62$ & $0,112 \pm 0,05$ & $0,360 \pm 0,17$ \\
\hline $16 / 08 / 02$ & Invemo & $1,496 \pm 0,44$ & $0,104 \pm 0,05$ & $0,400 \pm 0,79$ \\
\hline $06 / 09 / 02$ & Invemo & $2,368 \pm 0,76$ & $0,272 \pm 0,07$ & $2,640 \pm 1,51$ \\
\hline $12 / 09 / 02$ & Invemo & $3,112 \pm 0,93$ & $0,440 \pm 0,28$ & $0,520 \pm 0,23$ \\
\hline 03/10/02 & Primavera & $1,496 \pm 0,47$ & $0,160 \pm 0,12$ & $0,440 \pm 0,19$ \\
\hline $12 / 10 / 02$ & Primavera & $3,576 \pm 0,86$ & $0,136 \pm 0,07$ & $0,840 \pm 0,30$ \\
\hline $27 / 10 / 02$ & Primavera & $6,616 \pm 1,11$ & $0,328 \pm 0,30$ & $4,600 \pm 1,06$ \\
\hline 07/11/02 & Primavera & $5,240 \pm 0,89$ & $0,056 \pm 0,03$ & $2,760 \pm 0,80$ \\
\hline 21/11/02 & Primavera & $5,456 \pm 1,89$ & $0,240 \pm 0,14$ & $3,00 \pm 0,69$ \\
\hline $05 / 12 / 02$ & Primavera & $9,648 \pm 2,28$ & $0,040 \pm 0,03$ & $1,880 \pm 0,43$ \\
\hline $19 / 12 / 02$ & Primavera & $3,528 \pm 1,22$ & $0,016 \pm 0,02$ & $0,880 \pm 0,43$ \\
\hline $09 / 01 / 03$ & Verão & $4,456 \pm 0,78$ & $0,424 \pm 0,20$ & $0,960 \pm 0,24$ \\
\hline $31 / 01 / 03$ & Verão & $2,440 \pm 0,45$ & $0,632 \pm 0,18$ & $1,160 \pm 0,26$ \\
\hline $14 / 02 / 03$ & Verão & $1,760 \pm 0,33$ & $0,264 \pm 0,07$ & $0,800 \pm 0,41$ \\
\hline $27 / 02 / 03$ & Verão & $1,680 \pm 0,32$ & $0,224 \pm 0,07$ & $0,600 \pm 0,25$ \\
\hline Média total & & $2,35 \pm 0,46$ & $0,20 \pm 0,34$ & $1,10 \pm 0,22$ \\
\hline
\end{tabular}

* Média \pm erro padrão 
A respeito da ocorrência de cochonilhas no estrato inferior da planta (troncos e pernadas), verificou-se a presença da cochonilha Parlatoria cinerea (Figura 4B), com uma média de ocorrência de 1,10 $\pm 0,22$ cochonilhas em cada amostragem. O pico de ocorrência de $P$. cinerea foi 4,60 $\pm 1,06$ cochonilhas por amostra no início da primavera (Tabela 2 e Figura 6).

Da mesma forma que o observado no estrato superior da planta, notou-se que no estrato inferior o período de maior ocorrência de $C$. citricola foi concomitante com 0 aumento da incidência da cochonilha $P$. cinerea, observando-se uma correlação linear, positiva e significativa $(r=0,46 ; t=2,45$; $p=0,05)($ Figura 6$)$.

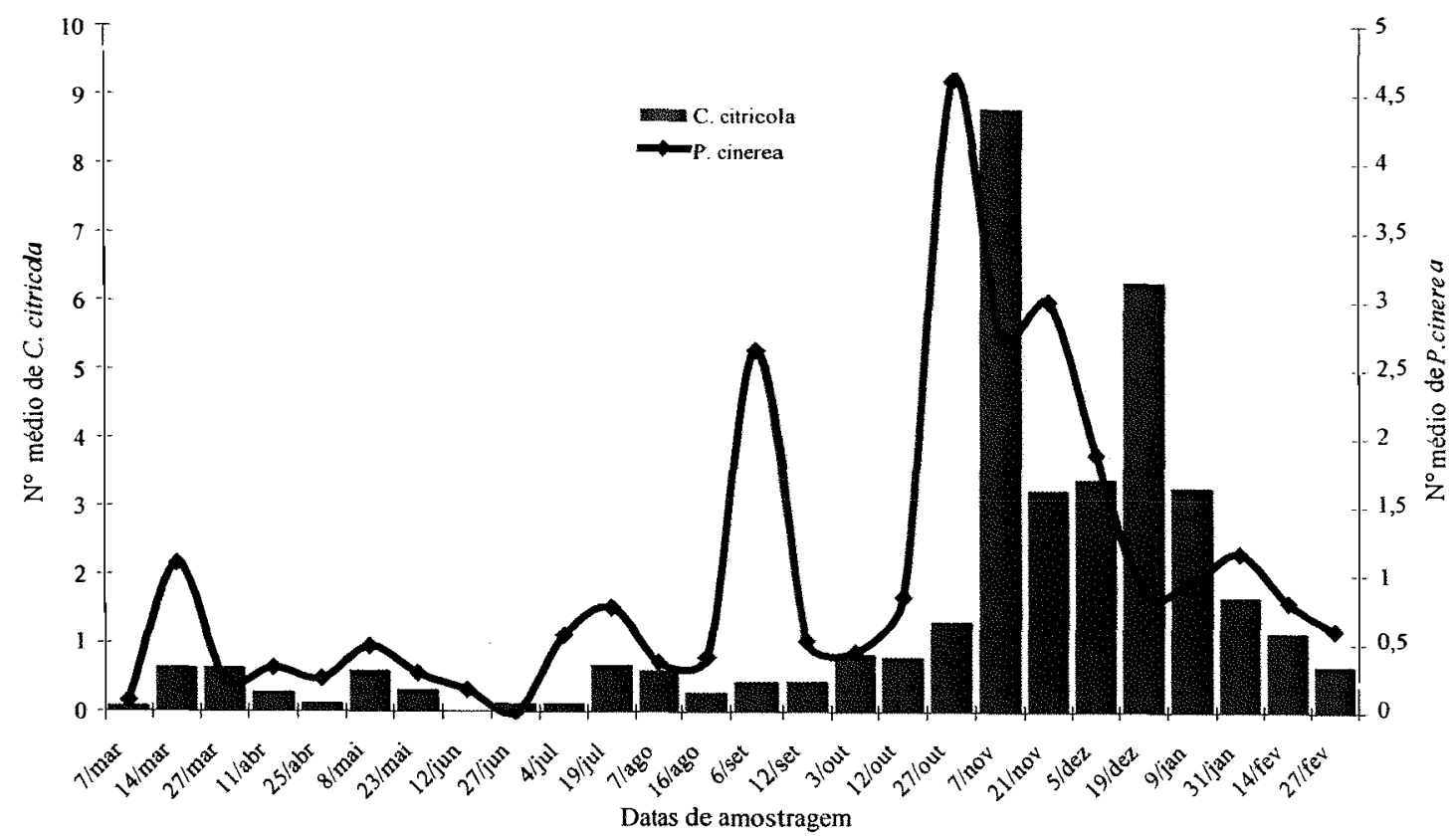

Figura 6 - Ocorrência estacional de $C$. citricola e $P$. cinerea (observadas no estrato inferior da planta de citros), durante o período de março/2002 a fevereiro/2003. Taiúva - SP

A joaninha $C$. citricola demonstrou ser um importante predador das cochonilhas de carapaça que ocorrem na cultura dos citros, tendo ocorrência constante durante todas as estações do ano, principalmente na primavera e 
verão, nas diferentes partes da planta, sendo um grande aliado no controle biológico de pragas.

\subsection{Conclusões}

Coccidophilus citricola é uma espécie classificada como constante na cultura dos citros, tanto no estrato superior, como no inferior da planta, onde age como predador de cochonilhas de carapaça.

A população de formas não migrantes, de C. citricola, como larvas, é maior a partir de meado da primavera ao início do verão, período em que ocorre abundância de presas, principalmente Parlatoria ziziphi, no estrato superior, e $P$. cinerea, no estrato inferior das plantas de citros. 


\section{OCORRÊNCIA ESTACIONAL DAS PRINCIPAIS ESPÉCIES DE COCCINELLIDAE PREDADORAS DE Toxoptera citricida (KIRKALDY, 1907) (HEMIPTERA: APHIDIDAE) NA CULTURA DOS CITROS}

\section{Resumo}

Este trabalho trata da ocorrência estacional de coccinelídeos predadores e do pulgão preto Toxoptera citricida. Para tanto foram realizadas amostragens quinzenais, em 25 plantas de um pomar comercial de citros localizado no município de Taiúva, SP, durante o período de março de 2002 a fevereiro de 2003. Em cada planta avaliou-se 4 brotações florais contendo 4 folhas, onde foram realizadas as observações quanto a presença do pulgão e dos coccinelideos predadores. O pulgão teve presença constante no agroecossistema citrícola, apresentando três picos populacionais, o primeiro em maio de 2002, o segundo em agosto do mesmo ano e o terceiro em meado de fevereiro de 2003. Os principais coccinelídeos observados neste período foram Diomus sp., Cycloneda sanguinea, Scymnus sp., Hippodamia convergens e Azya luteipes. Dentre as espécies observadas, Diomus sp. e Cycloneda sanguinea, foram consideradas constantes, tendo destacada correlação de ocorrência com o pulgão e importância na predação desta praga. 


\section{SEASONAL OCCURRENCE OF THE MOST IMPORTANT SPECIES OF COCCINELLIDAE PREYING Toxoptera citricida (KIRKALDY, 1907) (HEMIPTERA: APHIDIDAE) IN THE CITRUS CROP}

Summary

This paper deals with the seasonal occurrence of coccinellid species preying the brown citrus aphid, Toxoptera citricida. Fortnightly samples were randomly taken from 25 plants of a citrus commercial orchard located in Taiúva, State of São Paulo, Brazil, from March 2002 to February 2003. Four flowering buds containing four leaves from each plant were evaluated regarding the presence of the aphid and the preying coccinellids. The aphid was observed to be constant in the citrus agroecosystem, presenting three populations peaks: May 2002, August 2002 and February 2003. The main coccinellid species observed during the period (2002/2003) were: Diomus sp., Cycloneda sanguinea, Scymnus sp., Hippodamia convergens and Azya luteipes. From these species only Diomus sp. and Cycloneda sanguinea were considered constant ones, showing correlation with the pest and being important in the preying of the aphid. 


\subsection{Introdução}

A citricultura é uma das atividades agrícolas mais importantes no Brasil. É um setor que ocupa lugar de destaque gerando divisas e, principalmente, renda interna, empregos e contribuição em termos nutricionais (Nascimento et al., 1982; Neves, 1992; Borges \& Almeida, 2000; Agrianual, 2002).

Como a maioria das culturas implantadas, a citricultura é ameaçada por diferentes problemas fitossanitários, seja pelo ataque de pragas e doenças já presentes no Brasil, ou pela introdução de novos organismos.

No agroecossistema citrícola ocorrem várias pragas importantes, destacando-se cochonilhas, mosca-das-frutas, mosca branca, cigarrinhas, coleobrocas, tripes, lagartas e pulgões, além da presença de outros artrópodes como ácaros fitófagos (Gravena, 1984; Busoli, 1992; Pinto W.B.S, 1995; Paiva, 2000; Dantas, 2002; Ribeiro, 2002).

O controle das pragas que ocorrem no agroecossistema citricola tem sido realizado através de métodos culturais, biológicos e químicos, no entanto, os agricultores têm a tendência de utilizar mais os agrotóxicos em detrimento de outros métodos, principalmente, de forma intensa, que implica em desequilibrio ambiental (Gravena \& Lara, 1976).

O desequilibrio ambiental nos agroecossistemas tem propiciado efeitos maléficos e adversos à fauna benéfica, implicando no aparecimento de novas pragas, ou aumento dos problemas relacionados com pragas secundárias, como os surtos populacionais de cochonilhas e pulgões (De Bach, 1964; Dean et al., 1983; Gravena, 1990; Busoli, 1992).

Dentre as pragas que ocorrem nos citros destaca-se o pulgão preto, Toxoptera citricida (Kirkaldy), pois além de causar danos diretos, como a sucção contínua de seiva, implicando no enrolamento de brotações e folhas 
novas, e redução no desenvolvimento da planta, é uma das pragas com grande potencial para a transmissão de agentes causadores de doenças, como a 'tristeza dos citros', no passado, e a 'morte súbita dos citros', atualmente (Gravena, 2003).

O pulgão preto dos citros é o mais importante vetor do vírus que é agente causador da doença 'tristeza dos citros' (Meneghini, 1946; Costa \& Grant, 1951). A rápida dispersão da doença nos anos 30 e 40 causou a morte e erradicação de milhões de árvores de citros no Brasil e na Argentina (Yakomi et al., 1994; Michaud, 1999b).

Atribuindo o rápido desenvolvimento da doença na planta cítrica à alta suscetibilidade do porta enxerto utilizado na época, que era na sua maioria composto por laranja azeda, iniciou-se um processo de troca de porta enxertos, e o limão cravo, considerado tolerante à 'tristeza dos citros', ocupou o lugar do antigo porta enxerto (Meneghini, 1946; Müller, 1980).

Apesar da diminuição dos problemas decorrentes da ocorrência da 'tristeza dos citros' no pomar citrícola, atualmente tem surgido um novo problema para a citricultura brasileira, uma doença chamada de 'morte súbita dos citros', doença recente e praticamente desconhecida, que tem sido comparada com a 'tristeza dos citros', tendo, também, como possivel transmissor do agente causador da doença o pulgão T. citricida (Gravena, 2003).

Observando, então, a grande importância desta praga ao agroecossistema citrícola, vários pesquisadores têm trabalhado no sentido de determinar a flutuação populacional deste inseto e de seus possíveis inimigos naturais.

Dentre os inimigos naturais que ocorrem no agroecossistema citricola associados ao pulgão preto, destacam-se os coccinelídeos devido ao grande número de espécies associadas a esta praga, sua ocorrência constante no pomar, e por apresentar estreita ligação com sua presa (Hagen, 1962; Hagen, 1970; Hodek \& Honek, 1996; Michaud, 2000; Parra et al., 2003). 
Em nivel mundial, várias espécies foram relacionadas como predadoras do pulgão preto na cultura dos citros, dentre as quais, Chilocorus cacti (L.), Cladis nitidula (F.), Coccinella septempunctata L., Coleomegilla innotata (Mulsant), Coleomegilla maculata (Degeer), Coleophora inaequalis ( $F$.), Cycloneda sanguinea (L.), Diomus sp., Egius platycephalus Mulsant, Hippodamia convergens (Guerin), Hyperaspis sp., Nephapis sp., Olla v-nigrum (Mulsant), Procula ferruginea (Oliver), Scymnus floralis (F.) e Scymnus sp., (Lara et al., 1977; Chagas et al., 1982; Michaud, 1998; Michaud 2000).

Para as condições brasileiras, alguns coccinelídeos tiveram importância destacada no controle de $T$. citricida, sendo $C$. sanguinea, Scymnus sp., Diomus sp., Delphastus sp., Hyperaspis sp., sempre presentes em levantamentos realizados na cultura dos citros (Lara et al., 1977; Gravena, 1978; Gravena \& Fornasieri, 1979; Chagas et al., 1982; Santos et al., 1990; Parra et al., 2003).

Apesar do conhecimento de algumas espécies de coccinelídeos predadores que ocorrem nos citros, pouco se sabe sobre a ocorrência estacional destes predadores, bem como a correlação de ocorrência com o pulgão $T$. citricida. Com esta preocupação, o presente trabalho teve o objetivo de determinar as espécies de coccinelídeos predadores do pulgão preto, bem como a constância e a abundância destas espécies nas estações do ano.

\subsection{Material e Métodos}

O experimento foi conduzido num pomar comercial de citros Citrus sinensis (L.) variedade 'Pêra-Rio', constando de um talhão de 2000 plantas, com quatro anos de idade, localizado no município de Taiúva, SP, no estado de São Paulo. A área escolhida para o trabalho fazia parte de um convênio com o 
Centro de Manejo Integrado de Pragas (CEMIP), da UNESP/Jaboticabal, e visava a produção com a utilização mínima de inseticidas e fungicidas.

Durante o período de realização dos experimentos em campo, que constou das quatro estações no período de março de 2002 a fevereiro de 2003, foram realizadas amostragens quinzenais, sendo em cada amostragem avaliadas 25 plantas ao acaso, durante, aproximadamente, cinco minutos por planta.

Para a amostragem dos pulgões $T$. citricida foi realizado 0 caminhamento ao redor da planta, de onde se escolhia, de forma aleatória, quatro brotações. Uma brotação foi avaliada em cada um dos quadrantes da planta de citros, e em cada brotação, procedeu-se a visualização e contagem do pulgão preto dos citros, pois segundo Iperti (1999) e Lo (2000) a amostragem visual de insetos pragas e seus predadores é mais eficiente no agroecossistema citrícola, visto que a arquitetura da planta dificulta a utilização de outros métodos de amostragem de insetos.

Com a finalidade de realizar a identificação, alguns exemplares foram coletados e armazenados em álcool $70 \%$, sendo posteriormente comparados com pulgões identificados, mantidos pelo Departamento de Fitossanidade, FCAV, UNESP/Jaboticabal.

Juntamente com a amostragem realizada para o pulgão, procurou-se realizar a amostragem dos principais coccinelídeos predadores associados à presença ou não desta praga. Para isso, a presença de larvas e adultos dos coccinelídeos foi registrada na mesma brotação onde foi realizada a amostragem do pulgão. Da mesma forma que o realizado para o pulgão, alguns indivíduos foram coletados e armazenados em álcool $70 \%$, para posterior comparação com materiais identificados e mantidos pelo Departamento de Fitossanidade, FCAV, UNESP/Jaboticabal. As espécies não identificadas foram enviadas à Dra. Lúcia Massuti de Almeida, professora e pesquisadora da Universidade Federal do Paraná. 
De posse dos dados registrados em campo, determinou-se as principais espécies de coccinelídeos predadoras, a freqüência de ocorrência de cada espécie, bem como a correlação destes predadores com a do pulgão $T$. citricida. Com o estudo da porcentagem ocorrência das espécies de coccinelídeos nos levantamentos, foi calculada a constância de ocorrência das espécies estudadas, através da fórmula descrita por Silveira Neto et al. (1976):

$$
C=\frac{p x 100}{N}
$$

Onde: $\mathrm{C}=$ constância de ocorrência

$\mathrm{p}=$ número de amostragens contendo a espécie estudada

$\mathrm{N}=$ total de amostragens efetuadas

\subsection{Resultados e Discussão}

Com a amostragem foi possivel observar o pulgão preto $T$. citricida em seu hábitat preferencial (folhas novas e brotações) (Figura 1A e Figura 1B), e os predadores coccinelídeos relacionados a esta praga (Figura $1 \mathrm{C}$ ). Concordando com Hodek (1973), Iperti (1999) e Lo (2000), o método visual de contagem é funcional e rápido para coccinelídeos predadores e suas presas, comparado com os métodos manuais. 

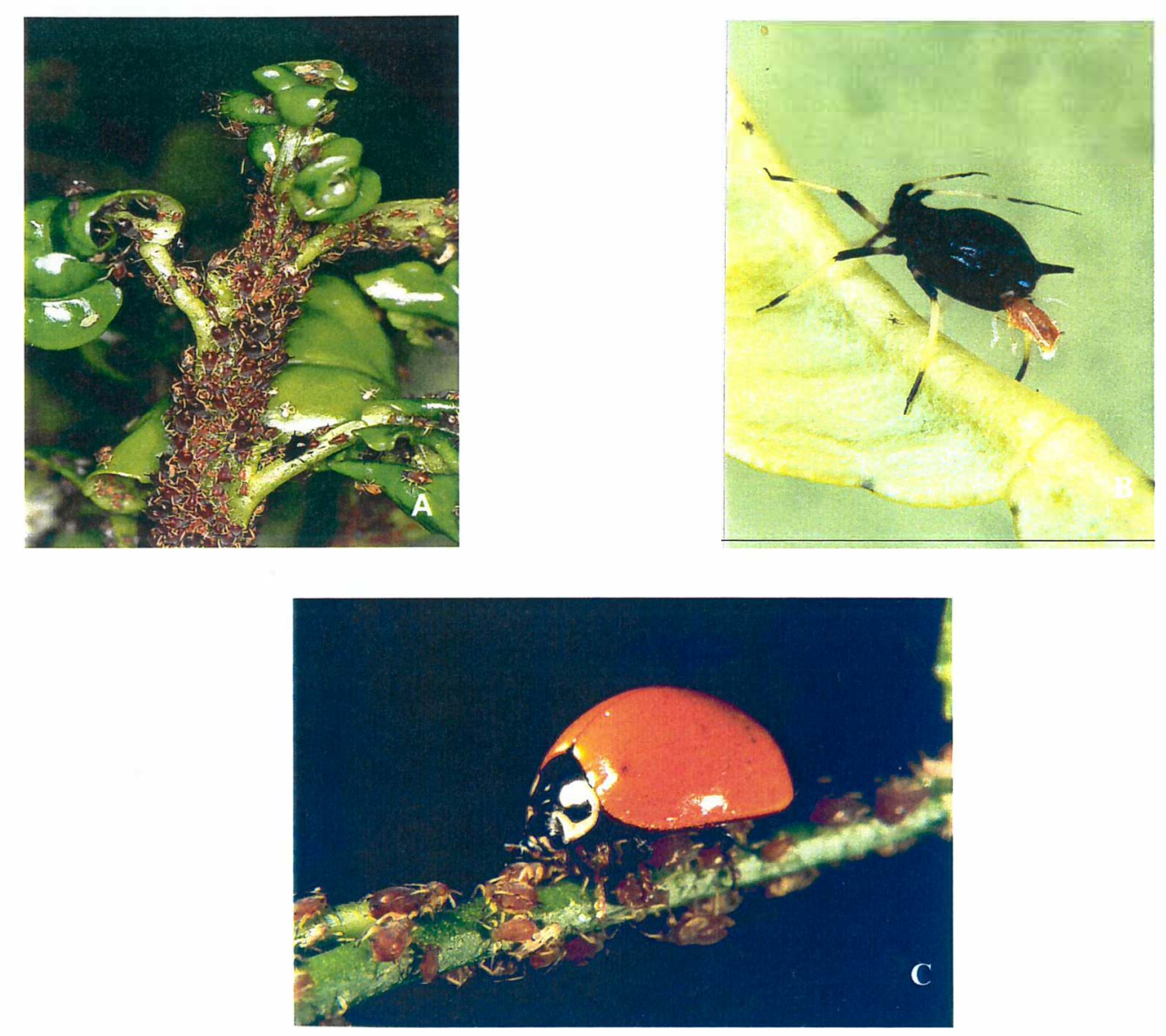

Figura 1 - Aspectos gerais de uma colônia de pulgões $T$. citricida em uma brotação $(A)$, detalhe de um espécime adulto colocando uma ninfa (B) e aspectos gerais de um coccinelídeo (C. sanguinea) alimentando-se do pulgão preto. (Fotografias: Heraldo Negri)

De acordo com a porcentagem de ocorrência de $T$. citricida nos levantamentos efetuados, notou-se que esta praga foi constante no agroecossistema citrícola, ocorrendo em $71 \%$ das amostragens. Pelos resultados, (Figura 2), nota-se que o pulgão preto ocorreu em dezessete amostragens, durante o período de março/2002 a fevereiro/2003, apresentando três picos populacionais bem definidos: o primeiro em maio de 2002, o segundo em agosto do mesmo ano e o terceiro em meado de fevereiro de 2003, sempre 
relacionados com períodos de crescimento vegetativo como o aparecimento de brotações ou em fases de florescimento (Figueiredo, 1980).

Estes resultados de ocorrência estacional de T. citricida foram semelhantes aqueles observados por Gravena (1978) para pomares da região de Jaboticabal, SP, na década de 1970. Como observado neste trabalho, a maior ocorrência de $T$. citricida no campo deu-se no mês de agosto, diferenciando das maiores populações encontradas em campo por Chagas et al. (1982), que observaram dois picos populacionais, em abril, e em novembro, sempre após a ocorrência de chuvas.

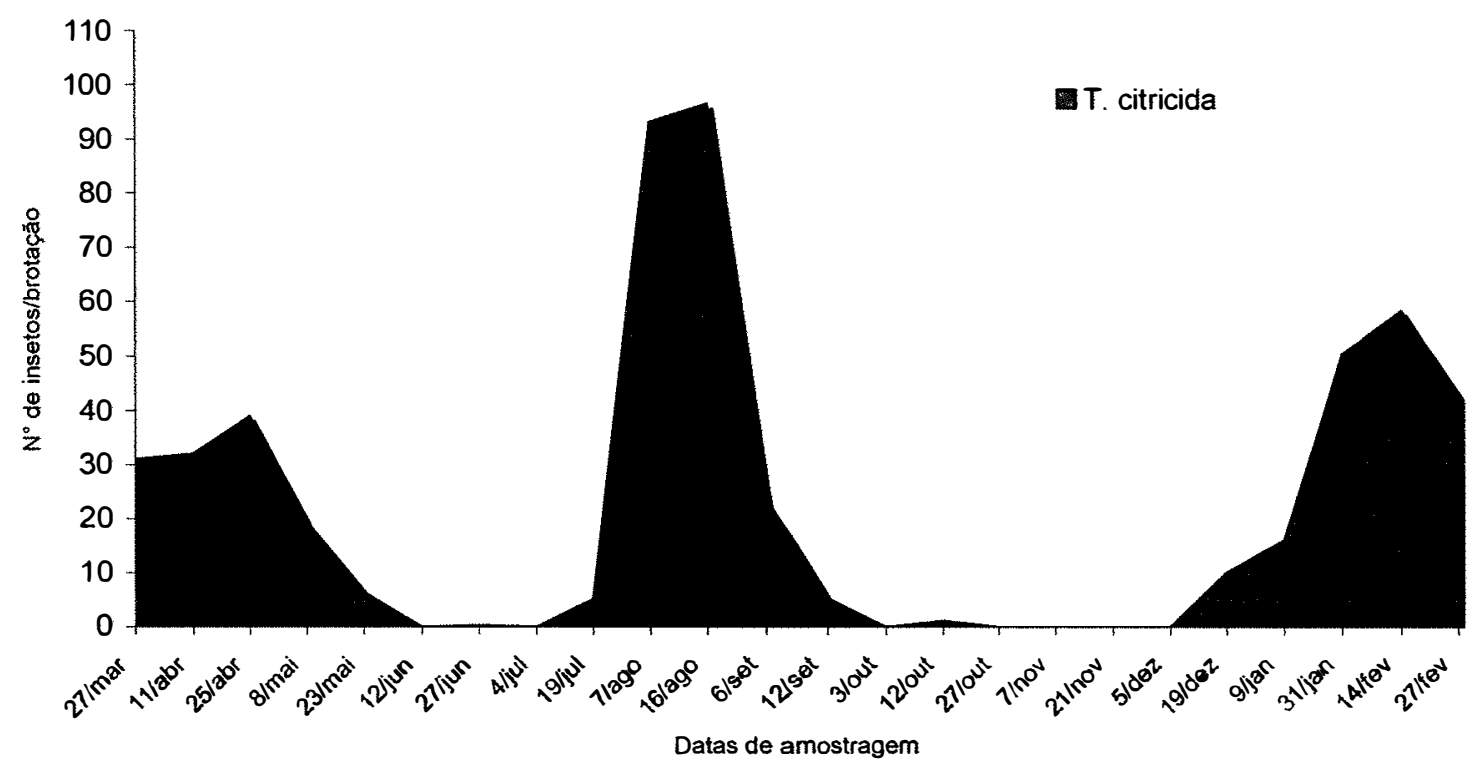

Figura 2 - Ocorrência estacional de $T$. citricida durante o período de março/2002 a fevereiro/2003. Taiúva - SP

Com relação aos predadores da família Coccinellidae, foram observadas cinco espécies mais representativas em termos de freqüência de observação na cultura dos citros, a saber: Diomus sp., Cycloneda sanguinea, Scymnus sp., Hippodamia convergens e Azya luteipes nas seguintes porcentagens de ocorrência: 70,95; 18,83; 7,15; 1,69 e 1,38, respectivamente (Figura 3). Segundo Ehler \& Miller (1978) e Hall \& Ehler (1979) a ocorrência de 
diversas espécies de coccinelídeos predadores no agroecossistema citrícola, pode ser relacionada à estabilidade apresentada por este ambiente, que segundo Wissinger (1997), faz com que estes inimigos naturais tenham maior efetividade no controle de pragas.

Tabela 1. Número médio de coccinelídeos predadores de T. citricida observados por brotação. Taiúva, SP, 2002/2003

\begin{tabular}{|c|c|c|c|c|c|}
\hline \multirow{2}{*}{$\begin{array}{c}\text { Datas de } \\
\text { Amostragem }\end{array}$} & \multicolumn{5}{|c|}{$N^{\circ} M E ́ D I O ~ C O C C I N E L I ́ D E O S *$} \\
\hline & Diomus sp. & C. sanguinea & Scymnus sp. & H. convergens & A. luteipes \\
\hline 27/03/02 & $1,32 \pm 0,69$ & $0,2 \pm 0,2$ & 0 & 0 & $0,16 \pm 0,12$ \\
\hline $11 / 04 / 02$ & $0,72 \pm 0,24$ & $1 \pm 0,72$ & $0,52 \pm 0,12$ & 0 & $0,04 \pm 0,04$ \\
\hline 25/04/02 & $1,00 \pm 0,24$ & $1,64 \pm 0,69$ & $0,6 \pm 0,19$ & 0 & $0,08 \pm 0,06$ \\
\hline 08/05/02 & $2,36 \pm 0,55$ & $0,52 \pm 0,23$ & $0,88 \pm 0,19$ & 0 & $0,12 \pm 0,09$ \\
\hline $23 / 05 / 02$ & $0,36 \pm 0,22$ & $0,08 \pm 0,08$ & $0,24 \pm 0,1$ & 0 & 0 \\
\hline $12 / 06 / 02$ & 0 & 0 & 0 & 0 & 0 \\
\hline $27 / 06 / 02$ & 0 & 0 & 0 & 0 & 0 \\
\hline 04/07/02 & 0 & 0 & 0 & $0,16 \pm 0,16$ & 0 \\
\hline 19/07/02 & $0,12 \pm 0,12$ & 0 & 0 & $0,12 \pm 0,12$ & 0 \\
\hline 07/08/02 & $7,48 \pm 1,47$ & $0,44 \pm 0,22$ & 0 & $0,36 \pm 0,16$ & 0 \\
\hline $16 / 08 / 02$ & $12,52 \pm 3,21$ & $0,24 \pm 0,1$ & 0 & $0,08 \pm 0,06$ & 0 \\
\hline 06/09/02 & $2,76 \pm 0,93$ & $0,44 \pm 0,18$ & 0 & $0,04 \pm 0,04$ & $0,04 \pm 0,04$ \\
\hline $12 / 09 / 02$ & $0,32 \pm 0,15$ & $0,16 \pm 0,07$ & 0 & 0 & $0,12 \pm 0,12$ \\
\hline 03/10/02 & $0,20 \pm 0,13$ & $0,04 \pm 0,04$ & 0 & 0 & 0 \\
\hline $12 / 10 / 02$ & $0,04 \pm 0,04$ & 0 & 0 & 0 & 0 \\
\hline 27/10/02 & $0,04 \pm 0,04$ & 0 & 0 & 0 & 0 \\
\hline 07/11/02 & $0,04 \pm 0,04$ & 0 & 0 & 0 & 0 \\
\hline 21/11/02 & $0,04 \pm 0,04$ & $0,08 \pm 0,08$ & 0 & 0 & 0 \\
\hline $05 / 12 / 02$ & 0 & 0 & 0 & 0 & $0,04 \pm 0,04$ \\
\hline $19 / 12 / 02$ & $0,24 \pm 0,13$ & 0 & 0 & 0 & 0 \\
\hline $09 / 01 / 03$ & $0,48 \pm 0,33$ & $0,20 \pm 0,08$ & 0 & 0 & 0 \\
\hline $31 / 01 / 03$ & $0,76 \pm 0,25$ & $0,64 \pm 0,44$ & $0,08 \pm 0,06$ & 0 & 0 \\
\hline $14 / 02 / 03$ & $3,68 \pm 0,74$ & $2,20 \pm 0,67$ & $0,12 \pm 0,07$ & 0 & 0 \\
\hline $27 / 02 / 03$ & $1,96 \pm 0,42$ & $1,72 \pm 0,45$ & 0 & 0 & 0 \\
\hline TOTAL & $1,52 \pm 0,59$ & $0,4 \pm 0,13$ & $0,10 \pm 0,03$ & $0,03 \pm 0,02$ & $0,03 \pm 0,01$ \\
\hline
\end{tabular}

* Média \pm erro padrão 
Frequência de ocorrência das espécies de coccinelídeos observadas

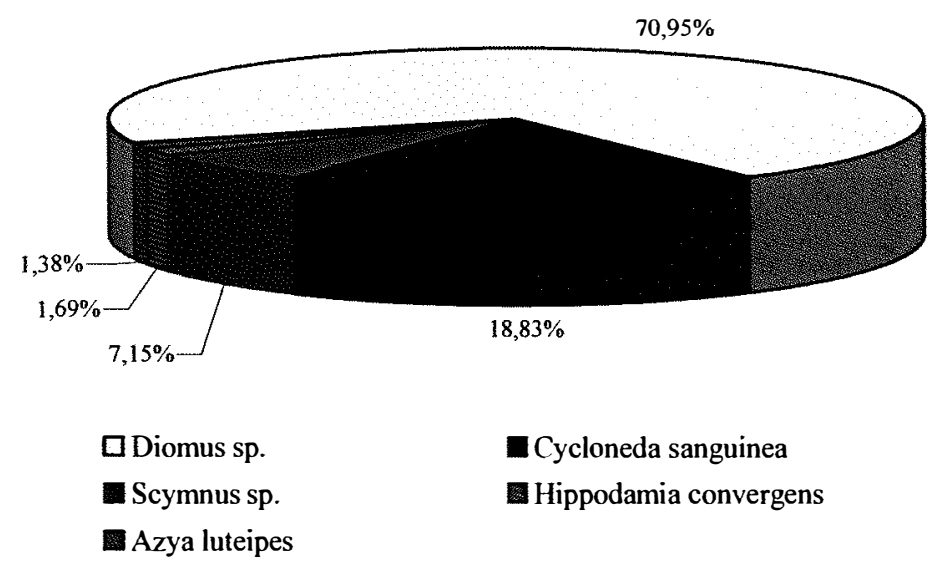

Figura 3 - Diversidade e freqüência de coccinelídeos observados durante o período de março/2002 a fevereiro/2003. Taiúva - SP

Portanto, dentre os coccinelídeos observados neste trabalho, Diomus sp. foi a espécie mais abundante, sendo considerada constante no agroecossistema citrícola estudado, visto que este predador ocorreu em $80 \%$ de todas as amostragens efetuadas, durante o período de março/2002 a fevereiro/2003.

Diomus sp. apresentou maior ocorrência em meado de agosto de 2002, com uma média de 12,52 $\pm 3,21$ joaninhas por brotação (Tabela 1). De acordo com os resultados, (Figura 4), nota-se que a joaninha Diomus sp. teve ocorrência semelhante com a ocorrência do pulgão $T$. citricida, e a presença deste predador foi correlacionada com a presença do pulgão, observando-se uma correlação linear positiva e significativa $(r=0,857 ; t=7,785 ; p=0,01)$, o que implica em dizer que com o aumento da população do pulgão preto, houve um aumento concomitante na população de Diomus sp., no agroecossistema. 


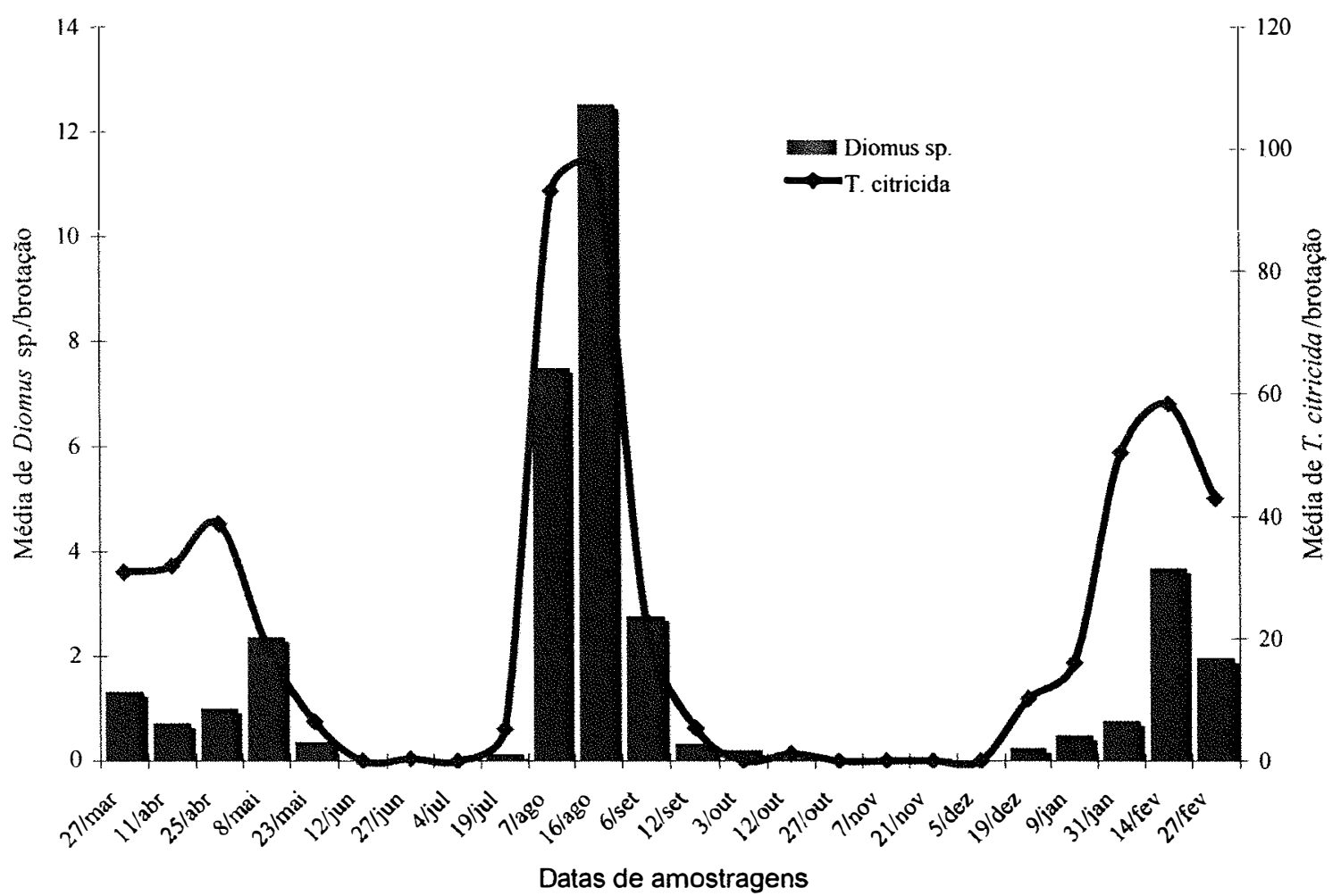

Figura 4 - Ocorrência estacional de Diomus sp. e de $T$. citricida, durante o período de março/2002 a fevereiro/2003. Taiúva - SP

A espécie Diomus sp. foi citada por Michaud (1998), em Porto Rico, como importante predadora de pulgões $T$. citricida, principalmente quando esta praga se encontrava na fase jovem de seu desenvolvimento. Já para as condições brasileiras, esta espécie de Coccinellidae foi relacionada como predador de $T$. citricida por Bartoszeck (1980) em Imperatriz, no estado do Maranhão, e por Santos et al. (1990), como uma das espécies ocorrentes em pomares citrícolas na região de Lavras, Minas Gerais. Para o estado de São Paulo, até então não havia registro desta espécie, como importante predador do pulgão preto.

A segunda espécie de coccinelídeo mais freqüente foi $C$. sanguinea. Segundo Silveira Neto et al. (1976), C. sanguinea pode, também, ser considerada uma espécie constante no agroecossistema citrícola, pois foi 
observada em $60 \%$ das amostragens realizadas durante o período estudado, diferente do encontrado por Chagas et al. (1982), que observaram que esta espécie contribuiu com uma população baixa, fazendo-se presente em poucas observações.

Da mesma forma que o ocorrido para Diomus sp., a presença de $C$. sanguinea foi correlacionada com a presença do pulgão preto, observando-se uma correlação linear, positiva e significativa $(r=0,6827 ; t=4,382 ; p=0,01)$, ou seja, o aumento da população da praga no campo, teve influência no aumento da população deste predador.

Como demonstrado, Figura 5, o pico de ocorrência de $C$. sanguinea foi observado em fevereiro de 2003 , com uma média de 2,20 $\pm 0,67$ espécimes por brotação (Tabela 1), diferindo do obtido por Lara et al. (1977) e Gravena (1978) que observaram picos de ocorrência nos meses de agosto e dezembro, respectivamente.

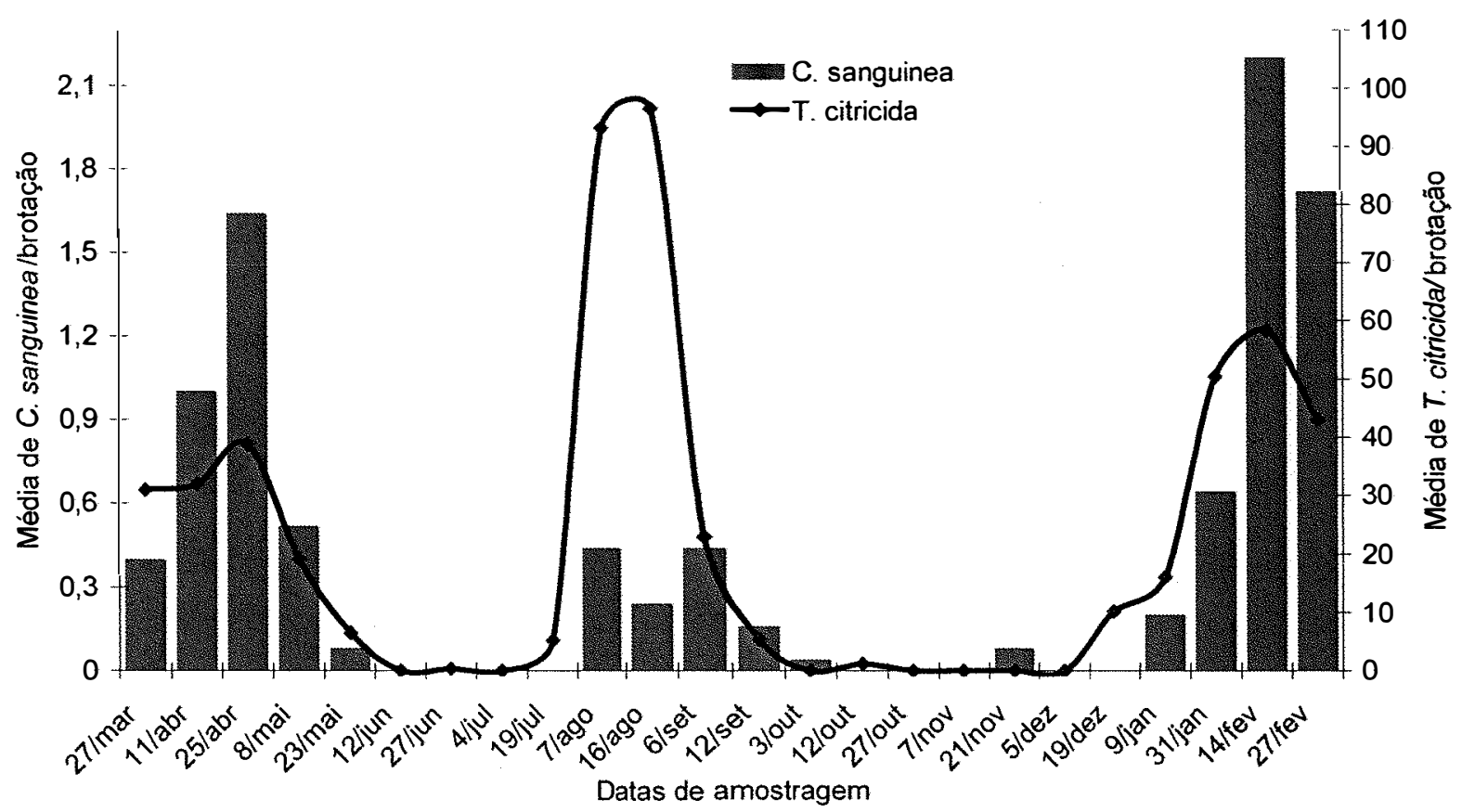

Figura 5 - Ocorrência estacional de $C$. sanguinea e de $T$. citricida, durante $o$ período de março/2002 a fevereiro/2003. Taiúva - SP 
Por estes resultados nota-se que $C$. sanguinea teve grande ocorrência no agroecossistema citrícola, no entanto, nas condições deste trabalho, não foi a espécie mais importante, discordando de Michaud (1998) e Michaud (1999a), que observou a destacada importância desta espécie, tanto em ocorrência no agroecossistema, como na predação do pulgão $T$. citricida.

Scymnus sp. foi a terceira espécie em termos de freqüência nas amostragens e, ao contrario das duas anteriores, foi considerada uma espécie acessória, pois esteve presente em, apenas, $28 \%$ das amostragens efetuadas, ou seja, ocorreu no agroecossistema citrícola, no entanto, sua relação com o pulgão preto foi secundária, estando, provavelmente, relacionada com outras presas.

O pico populacional de ocorrência desta espécie foi obtido em maio de 2002, com média de 0,88 0 0,19 coccinelídeos/brotação (Tabela 1 e Figura 6), diferindo do observado por Chagas et al. (1982), que obtiveram pico de ocorrência em meado de dezembro, além disso, Scymnus sp. contribuiu com uma população relativamente baixa, não sendo correlacionada com a presença do pulgão na área estudada.

As demais espécies de coccinelídeos, ou seja, Azya luteipes e Hippodamia convergens, tiveram ocorrência restrita em poucas amostragens, apresentando um baixo número de indivíduos amostrados (Tabela 1 e Figura 7). Estes resultados concordam com Michaud (1998) e Gravena (1980), que relacionaram a possivel ocorrência destes predadores com o pulgão preto, mas a importância destas espécies não foi enfatizada, por, provavelmente, apresentarem preferência por outras espécies de presas. 


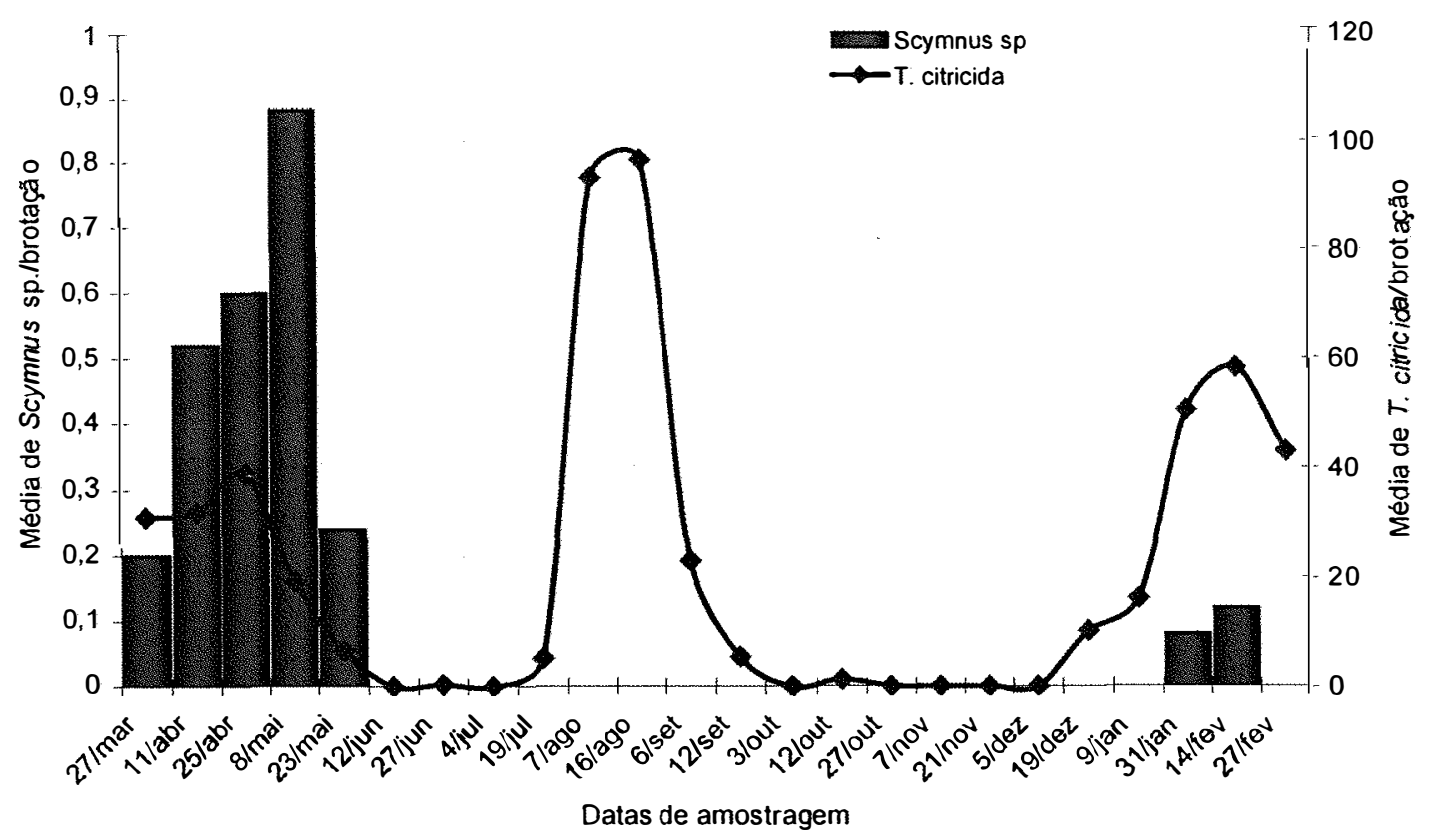

Figura 6 - Ocorrência estacional de Scymnus sp e de $T$. citricida, durante o período de março/2002 a fevereiro/2003. Taiúva - SP

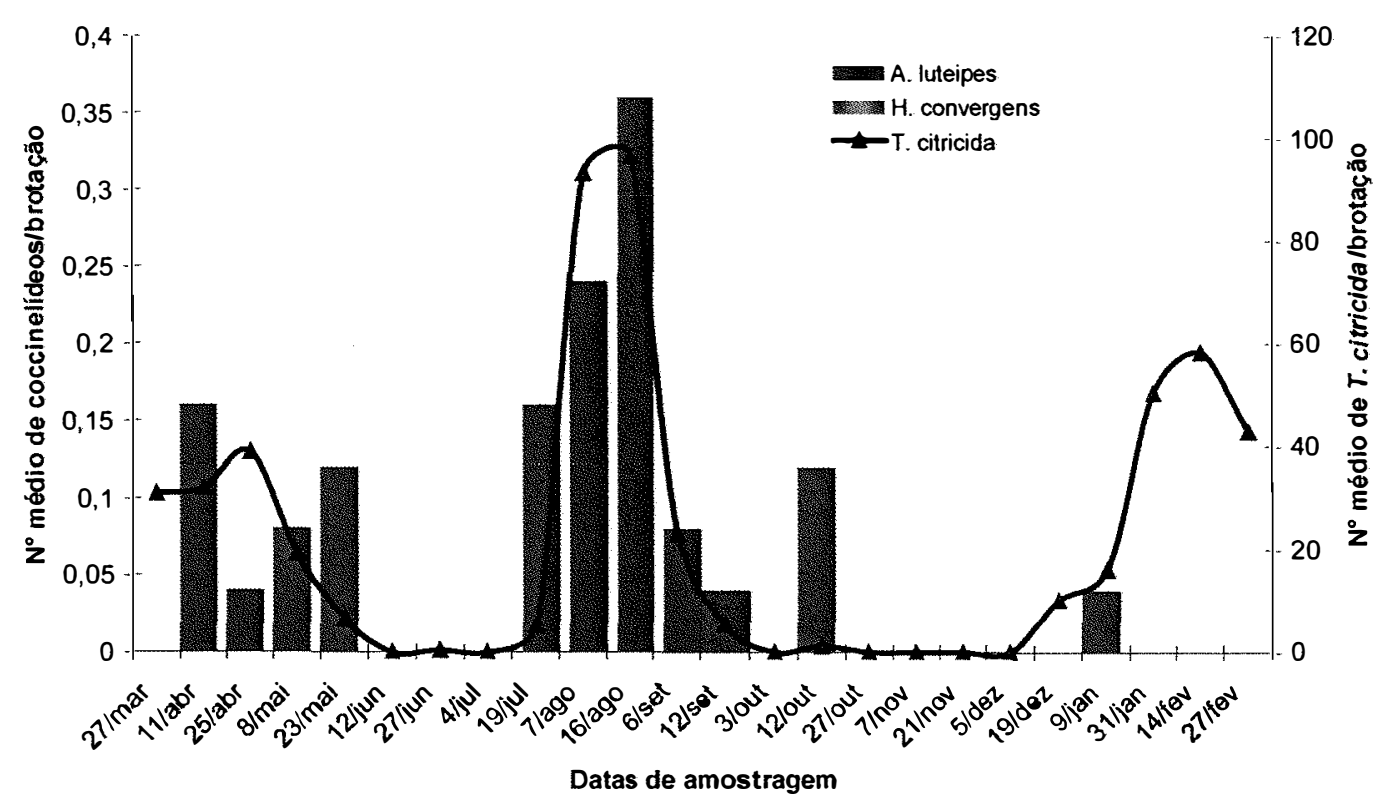

Figura 7 - Ocorrência estacional de Hippodamia convergens e Azya luteipes e de $T$. citricida, durante o período de março/2002 a fevereiro/2003. Taiúva - SP 


\subsection{Conclusões}

Diomus sp. e Cycloneda sanguinea são espécies constante no agroecossistema citrícola, agindo como bons predadores do pulgão Toxoptera citricida.

A população do pulgão Toxoptera citricida e de seus predadores Diomus sp. e Cycloneda sanguinea é mais abundante em períodos de maior brotação na planta. 


\section{CONCLUSÕES GERAIS}

- Os insetos pertencentes à família Coccinellidae são importantes inimigos naturais de cochonilhas e pulgões na cultura dos citros;

- Os coccinelídeos podem ser observados nas diferentes estações do ano (mesmo em épocas consideradas desfavoráveis), no agroecossistema citrícola;

- A ocorrência estacional dos coccinelídeos está intimamente relacionada à ocorrência de suas presas;

- Coccidophilus citricola, Diomus sp., e Cycloneda sanguinea são constantes no agroecossistema citrícola, atuando como predadores de cochonilhas e pulgões. 


\section{REFERÊNCIAS BIBLIOGRÁFICAS}

FNP CONSULTORIA \& COMERCIO. AGRIANUAL 2002: Anuário da agricultura brasileira. São Paulo, 2002. 434 p.

ALMEIDA, L.M. Notas e descrições em Psylloborini (Coleoptera: Coccinellidae). Revista Brasileira de Entomologia, v.36, n.4, p.760-765, 1992.

ANDRADE, L. L.; GUERREIRO, J. C.; VERONEZZI, F. R.; BARBOSA, R. L.; BUSOLI, A. C.; BERTI FILHO, E. Diversidade de coccinelídeos predadores na cultura do milho (Zea mays L.) em Jaboticabal, SP. In: SIMPÓSIO DE CONTROLE BIOLÓGICO, 3. São Pedro, 2003. Resumos/l São Pedro: Sociedade Entomológica do Brasil, 2003. p.140

ARAUJO, R.L. As joaninhas úteis. O Biológico, v.6, p.94-97, 1940.

ARRUDA FILHO, G.P.; ARRUDA, G.P. Manejo integrado da cochonilha Diaspis echinocacti praga da palma forrageira em Brasil. Manejo Integrado de Plagas y Agroecologia, v.64, p.1-6, 2002.

BARTRA. P.C.E. Biologia de Selenaspidus articulatus Morgan y sus principales controladores biologicos. Revista Peruana de Entomologia, v.17, n.1, p.60-68, 1974. 
BARTOSZECK, A.B. The occurrence of Toxoptera citricidus (Homoptera: Aphididae) and its natural enemies in Imperatriz, Maranhao, Brazil. Dusenia, v.12, p.9-13, 1980.

BERTI FILHO, E. O controle biológico dos insetos-praga. In: CROCOMO, W.B. Manejo Integrado de pragas. São Paulo: UNESP/CETESB, 1990. cap.5, p. $87-109$.

BORGES, R. S.; ALMEIDA, F. J. Câmbios em la producción de plantones citricos em Brasil. Todo citrus, v.3, n.8, p.5-12, 2000.

BROWN, M.W. Resilience of the natural arthropod community on apple to external disturbance. Ecological Entomology, v.18, p.169-183, 1993.

BUSOLI, A.C. Uso do enxofre em citros e dinâmica populacional de cochonilhas e ácaros. Laranja, v.13, p.353-395, 1992.

CALTAGIRONE, L.E.; DOUTT, R.L. The history of the vedalia beetle importation to California and its impact on the development of biological control. Annual Review of Entomology, v.34, p.1-16, 1989.

CAMPOS, A.R.; GRAVENA, S.; BERTOZO, R.; BARBIERI, J. Artropodos predadores na cultura algodoeira e comparação de métodos de amostragem. Anais da Sociedade Entomológica Brasil, v.15, Supl. p.519, 1986.

CAMPOS, J.S.; ASSIS, A.F.F.; BERTINI, K.; LALVIU NETO; LEVY, H. Cultura dos citros. São Paulo: CATI, 1973. 61p. 
CHAGAS, E.P.; SILVEIRA NETO, S.; BRAZ, A.J.B.P.; MATEUS, C.P.B.; COELHO, I.P. Flutuação populacional de pragas e predadores em citros. Pesquisa Agropecuária Brasileira, v.17, n.3, p.817-824, 1982.

CHAVES, L.E.L.; BERTI FILHO, E.; LOURENÇÃO, A.L. Espécies de Coccinellidae da coleção do Instituto Agronômico de Campinas. Revista de Agricultura, v.66, n.2, 1991.

CORBETT, A.; ROSENHEIM, J.A. Impact of a natural enemy over wintering refuge and its interaction with the surrounding landscape. Ecological Entomology, v.21, p.155-164, 1996.

CORREIA, A.C.B.; BERTI FILHO, E. Aspectos biológicos de Cycloneda zischkai Mader, 1950 (Coleoptera, Coccinellidae), predador de psilídeos. Anais da Sociedade Entomológica do Brasil, v.17, n.2, p.335-345, 1988.

COSTA, A.S., GRANT, T.J. Studies on transmission of the tristeza virus by the vector Aphis citricidus. Phitopathology, v.16, p.105-133, 1951.

DANTAS, I. M. Distribuição espacial e plano de amostragem seqüencial para a lagarta do minador-dos-citros Phyllocnistis citrella Stainton 1856 (Lepidoptera: Gracillariidae) em laranjeira 'pêra-rio' Citrus sinensis (L.) Osbeck. Jaboticabal, 2002. 63p. Tese (Doutorado) - Faculdade de Ciências Agrárias e Veterinárias, Universidade Estadual Paulista "Julio de Mesquita Filho".

DEAN, H. A.; FRENCH, J. V.; MEYERDIRK, D. Development of integrated pest management in Texas citrus. Texas: Agricultural experimental Station, 1983. $15 \mathrm{p}$. 
De $\mathrm{BACH}, \mathrm{P}$. Biological control of insects pests and weeds. New York: Reinhold Publ., 1964. 844p.

DE BORTOLI, S.A.; BENVENGA, S.R.; GRAVENA, S.; MIRANDA, J.E. Biologia de Pentilia egena Mulsant (Coleoptera: Coccinellidae) e predação sobre Chrysomphalus ficus Ashmead (Homoptera: Diaspididae). Boletín de Sanidad Vegetal Plagas, v.27, p.337-343, 2001.

DIXON, A.F.G.; HEMPTINNE, J.L.; KINDLMANN, P. Effectiveness of ladybirds as biological control agents: patterns and processes. Entomophaga, v.42, p.71-83, 1997

DOMENICI, M. G. Aspectos biológicos e seletividade de acaricidas a Coccidophilus ctricola Brèthes, 1905 (Coleoptera: Coccinellidae). Jaboticabal, 1998. 96p. Dissertação (Mestrado) - Faculdade de Ciências Agrárias e Veterinárias, Universidade Estadual Paulista "Julio de Mesquita Filho".

EHLER, L.E.; MILLER, J.C. Biological control in temporary agroecossystems. Entomophaga, v.3, p.207-212, 1978.

ELLIOTT, N.C.; KIECKHEFER, R.W.; BECK, D.A. Adult coccinellid activity and predation on aphids in spring cereals. Biological Control, v.17, p.218-226, 2000.

FIGUEIREDO, J.O. Variedades-copa de valor comercial. In: RODRIGUEZ, O.; VIÉGAS, C. P. Citricultura brasileira. Campinas: Fundação Cargill, 1980, cap.10, p.243-273. 
FRAZER, B.D., RAWORTH, D.A. Sampling for adults coccinellids and their numerical response to strawberry aphids (Coleoptera: Coccinellidae: Homoptera: Aphididae). The Canadian Entomologist, v.117, p.153-161, 1985.

FUTUYMA, D.J. Biologia evolutiva. Ribeirão Preto: Sociedade Brasileira de Genética/CNPq, 1997.646p.

GORDON, R.D. The Coccinellidae (Coleoptera) of America and north of Mexico. Journal of New York Entomological Society, v.93, n.1, p.1-912, 1985.

GRAVENA, S. Ocorrência de parasitismo em Cycloneda sanguinea (Linnaeus 1753), no município de Jaboticabal, SP, Brasil. Anais da Sociedade Entomológica do Brasil, v.7, n.1, p.69-70, 1978.

GRAVENA, S. Controle integrado de pragas dos citros. In: RODRIGUEZ, O.; VIÉGAS, C. P. Citricultura brasileira. Campinas: Fundação Cargill, 1980, cap.24, p.645-683.

GRAVENA, S. O controle biológico na cultura algodoeira. Informativo Agropecuário, v.9, n.104, p.3-15, 1983.

GRAVENA, S. Manejo integrado de pragas dos citros. Laranja, v.5, p.323-361, 1984.

GRAVENA, S. Parlatoria pergandii Comstock e primeiros resultados de observações e controle na citricultura brasileira. Laranja, v.1, p.45-57, 1986. 
GRAVENA, S. Manejo integrado de pragas de citrus na atualidade. In: FERNANDES, O. A.; CORREIA, A. C. B.; BORTOLI, S.A. Manejo integrado de pragas e nematóides. Jaboticabal: FUNEP,1990. v.1, p.107126.

GRAVENA, S. O pulgão e a morte súbita dos citros.Coopercitrus Informativo Agrupecuário, v.17, n.197, p.26, 2003

GRAVENA, S.; LARA, F. M. Efeito de alguns inseticidas sobre predadores entomófagos em citros. Anais da Sociedade Entomológica do Brasil, v.5, n.1, p.39-42, 1976.

GRAVENA, S.; FORNASIERI, J.L. Flutuação populacional de algumas cochonilhas de carapaça e predadores entomófagos em citrus, e influência de fatores meteorológicos. Científica, v. 7, n.1, 109-113, 1979.

GUERREIRO, J.C. Aspectos bioecológicos e metodologias de criação massal da joaninha Pentilia egena Mulsant (Coleoptera: Coccinellidae). Jaboticabal, 1998. 49p. Monografia (Graduação) - Faculdade de Ciências Agrárias e Veterinárias, Universidade Estadual Paulista "Julio de Mesquita Filho".

GUERREIRO, J.C. Aspectos morfológicos e bioecológicos de Pentilia egena Mulsant, 1850 (Coleoptera: Coccinellidae). Jaboticabal, 2000. 94p. Dissertação (Mestrado) - Faculdade de Ciências Agrárias e Veterinárias, Universidade Estadual Paulista "Julio de Mesquita Filho".

GUERREIRO, J.C.; SILVA, R.A.; BUSOLI, A.C. Comportamento de oviposição de Pentilia egena Mulsant 1850 (Col.: Coccinellidae) In: CONGRESSO DE ECOLOGIA DO BRASIL, 4, Porto Alegre, 2001. Resumos// Porto Alegre: Sociedade Brasileira de Ecologia, 2001. p.16. 
GUERREIRO, J. C.; BERTI FILHO, E.; BUSOLI, A. C. Oviposition and predation of Pentilia egena Mulsant (COLEOPTERA:COCCINELLIDAE) in response to temperature. Scientia Agricola, v.60, n.3, p. 587-589, 2003.

GUERREIRO, J.C., SILVA, R.A. BUSOLI, A.C., BERTI FILHO., E. Coccinelídeos predadores que ocorrem no estágio inicial da cultura do algodoeiro em Jaboticabal, SP, Brasil. Revista de Agricultura, v. 77, n. 1, p. 161-168, 2002.

HAGEN, K.S. Biology and ecology of predaceous Coccinellidae. Annual Review of Entomology, v.7, p.289-326, 1962.

HAGEN, K.S. Following the ladybug home. National Geographic, v.137, n.4, p.542-553, 1970.

HALL, R.W.; EHLER, L.E. Rate of establishiment of natural enemies in classical biological control. Bulletin of the Entomological Society of America., v.25, p.280-282, 1979.

HODEK, I. Bionomics and ecology of predaceous Coccinellidae. Annual Review of Entomology, v.12, p.289-326, 1967.

HODEK, I. Biology of Coccinellidae. Prague, Czechoslovak: Academy of Sciences, 1973. 260p.

HODEK, I.; HONEK, A. Ecology of Coccinellidae. Dordrecht: Kluver Academic, 1996. 464p. 
HOLST, N.; RUGGLE, P. A physiologically based model of pest-natural enemy interactions. Experimental and Applied Acarology, v.21, p. 325-341, 1997.

IPERTI, G. Contribution à l'étude de la spécificité chez les principalis coccinelles aphidiphages des Alpes Maritimes et des Basses-Alpes. Entomophaga, v.9, p.153-180, 1965.

IPERTI, G. Biodiversity of predaceous Coccinellidae in relation to bioindication and economic importance. Agriculture, Ecosystems and Environment, v.74, p.323-342, 1999.

IVES, P.M. Feeding and egg production of two species of Coccinellidae in the laboratory. The Canadian Entomologist, v.113, p.999-1005, 1981.

KUZNETSOV, V.N. Lady beetles of the Russian far east. Gainesville: The Sandhill Crane Press, 1997. 248p.

LARA, F.M.; DE BORTOLI, S.A.; OLIVEIRA, E.A. Flutuações populacionais de alguns insetos associados ao Citrus sp. e suas correlações com fatores meteorológicos. Científica, v.5, n.2, p.134-143, 1977.

LEÃO NETO, R. R.; GRAVENA, S.; MORETTI, F.C.; TOZATTI, G. Eficiência de inseticidas sobre a cochonilha Selenaspidus articulatus (Morgan) (Homop., Diaspididae) e efeito sobre inimigos naturais no pomar cítrico. In: CONGRESSO BRASILEIRO DE ENTOMOLOGIA 10, Rio de Janeiro, 1986 Resumos// Rio de Janeiro: Sociedade Entomológica do Brasil, 1986. p.85 
LO, P. L. Species and abundance of ladybirds (Coleoptera: Coccinellidae) on citrus orchards in northland, New Zealand, and comparison of visual and manual methods of assessment. New Zealand Entomologist, v.23, p. 61$65,2000$.

MARICONI, A.M. Inseticidas e seu emprego no combate as pragas. São Paulo: Agronômica Ceres, 1963.607p.

MENEGHINI, M. Sobre a natureza e transmissibilidade da doença "Tristeza dos citros". O Biológico, v.12, p. 285-287, 1946.

MICHELOTTO, M.D.; SILVA,R.A.; GUERREIRO, J.C.; BUSOLI, A.C. Diversidade e abundância de coccinelídeos em seis cultivares de algodoeiro (Gossypium hirsutum L.). Boletín de Sanidad Vegetal Plagas, v.29, n.2, p.219-226, 2003.

MICHAUD, J.P. A review of the literature on Toxoptera citricida (Kirkaldy) (Homoptera: Aphididae). Florida Entomologist, v.81, n.1, p.37-61, 1998.

MICHAUD, J.P. Aggregation by alatae of Toxoptera citricida (Homoptera: Aphididae). Population Ecology, v.28, n.2, p.205-211, 1999.a

MICHAUD, J.P. Sources of mortality in colonies of brown citrus aphid, Toxoptera citricida. BioControl, v.44, p.347-367, 1999.b

MICHAUD, J.P. Development and reproduction of ladybeetles (Coleoptera: Coccinellidae) on the citrus aphids Aphis spiraecola Patch and Toxoptera citricida (Kirkaldy) (Homoptera: Aphididae). Biological Control, v.18, p.287297, 2000. 
MORAES, L.A.H.; PORTO, O.M.; BRAUN, J. Pragas de citros. Porto Alegre: Fepagro, 1995. 33p.

MOREIRA, S. Observações sobre a "tristeza" dos citros ou podridão da radicelas. O Biológico, v.8, p.269-272, 1942.

MÜLLER, G.W. Moléstia de vírus e micoplasmas de citros. In: RODRIGUEZ, O.; VIÉGAS, C. P. Citricultura brasileira. Campinas: Fundação Cargill, 1980. cap.21, p.567-584.

NASCIMENTO, A. S.; MORAIS, G. J.; CABRITA, J. R. M.; SILVA, I. M. S.; PORTO, O. M.; CASSINO, P. C. R.; GRAVENA, S.; PINTO, W. B. S. Manual de manejo integrado das pragas do pomar cítrico. Brasília: EMBRAPA-DID, 1982. 48p.

NEVES, E. M. Citricultura brasileira: importância econômica e perspectives. Laranja, v.13, n.2, p.55-62, 1992.

OBRYCKI, J.J.; KRING, T.J. Predaceous Coccinellidae in biological control. Annual Review of Entomology, v.43, p.295-321, 1998.

OLIVEIRA, A.E. Atratividade de cores a alguns insetos associados aos Citrus sp., suas flutuações populacionais e correlaçōes com fatores meteorológicos. Jaboticabal, 1976. 93p. Monografia (Graduação) Faculdade de Ciências Agrárias e Veterinárias, Universidade Estadual Paulista "Julio de Mesquita Filho".

OLKOWSKI, W.; SHANG, A.; THIERS, P. Improved biocontrol techniques with lady beetles. IPM-Practioner, v.12, p.1-12, 1990. 
PAIVA, P. E. B.; GRAVENA, S.; AMORIM, L. C. S. Introdução do parasitóide Ageniaspis citricola Logvinovskaya para o controle biológico da minadora das folhas dos citros Phyllocnistis citrella Stainton 1856 no Brasil. Laranja, v.21, n.2, p.217-288, 2000.

PARRA, J.R.P.; OLIVEIRA, H.N.; PINTO, A.S. Guia ilustrado de pragas e insetos benéficos dos citros. Piracicaba: A.S. Pinto, 2003. 140p.

PINTO, A.S. Flutuação populacional de Selenaspidus articulatus (Morgan) (Hemíptera: Diaspididae) em citros e ocorrência de inimigos naturais no município de Taquaritinga - SP. Jaboticabal, 1995. 100p. Dissertação (Mestrado) - Faculdade de Ciências Agrárias e Veterinárias, Universidade Estadual Paulista "Julio de Mesquita Filho".

PINTO, W. B. S. Coleobrocas e cochonilhas dos citros. Laranja, v.16, n.2, p.8795, 1995.

POPPY, G.M. Tritrophic interactions:improving ecological understanding and biological control? Endeavour, v.21, n.2, p.61-65, 1997.

PRATES, H.S.; CABRITA, J.R.; PINTO, W.B.S. Selenaspidus articulatus uma praga em potencial para a citricultura paulista. Campinas: CATI, 1985, 35p.(Comunicado Técnico)

PUTMAN, W.L. Laboratory studies on the food of some coccinellids (Coleoptera) found in Ontario peach orchards. The Canadian Entomologist, v.89, p.527-579, 1957. 
PUTMAN, W.L. Occurrence and food of some coccinellids (Coleoptera) in Ontario peach orchards. The Canadian Entomologist, v.96, p.1149-1155, 1959.

PUZZI, D. Pragas dos pomares de citros e seu combate. São Paulo: EDANEE, 1966, 58p.

RIBEIRO, L.J. Inimigos naturais da lagarta minadora dos citros Phyllocnistis citrella Stainton, 1856 (Lepidoptera: Gracillariidae) no Brasil. Piracicaba, 2002. 81p. Tese (Doutorado) - Escola Superior de Agricultura "Luiz de Queiroz", Universidade de São Paulo.

ROMERO, R.R.; CUEVA, M.C.; OJEDA, D.P. Morfologia, ciclo biologico de Scymnus (Pullus) sp. (Col.: Coccinellidae). Revista Peruana de Entomologia, v.17, n.1, 1974.

ROSENHEIM, J.A.; WILHOIT,L.R.; GOODELL, P.B.; GRAFTON-CARDWELL, E.E.; LEIGH, T.F. Plant compensation, natural biological control, and herbivory by Aphis gosypii on prereproductive cotton: the anatomy of a nonpest. Entomologia Experimentalis et Applicata, v.85, p.45-63, 1997.

SALOMON, M.E. Population dynamics. Londres: Edward Arnold, Study, v.18, 59p, 1969.

SANTOS, A. C. Aspectos bioecológicos e seletividade de agroquímicos a Coccidophilus ctricola Brèthes (Coleoptera: Coccinellidae). Jaboticabal, 1995. 91p. Dissertação (Mestrado) - Faculdade de Ciências Agrárias e Veterinárias, Universidade Estadual Paulista "Julio de Mesquita Filho". 
SANTOS, A.C.; GRAVENA, S. Técnicas de criação de Coccidophilus citricola Brèthes (Coleoptera: Coccinellidae). In: Congresso de Iniciação Científica da UNESP, 3, Jaboticabal, 1991. Resumos/l Jaboticabal: UNESP, 1991. p.81.

SANTOS, A.C.; PAIVA, P.E.B.; GRAVENA, S. Inimigos naturais da cochonilha Parlatoria ziziphus Lucas (Hemiptera: Diaspididae) em citros na região de Jaboticabal. In: SIMPÓSIO DE CONTROLE BIOLÓGICO, 3, Águas de Lindóia, 1992. Resumos/l Águas de Lindóia: Sociedade Entomológica do Brasil, 1992. p.321.

SANTOS, O.D.; BUENO, V.H.P.; BERTI FILHO, E. Coccinelídeos predadores que ocorrem em diversas culturas na região de Lavras, MG. Revista de Agricultura de Piracicaba, v.65, n.3, p.233-238, 1990.

SANTOS, T.M.; BUENO, V.H.P. Efeito da temperatura sobre o desenvolvimento de Scymnus (Pullus) argentinicus (Coleoptera: Coccinellidae). Pesquisa Agropecuária Brasileira, v.34, n.6, p.1093-1099, 1999.

SASAJI, H. Fauna Japonica. Coccinellidae (Insecta: Coleoptera). Fukui: Academia Press of Japan, 1971. 345p.

SILVA, R. A. Aspectos bioecológicos e caracterização morfológica de Coccidophilus ctricola Brèthes, 1905 (Coleoptera: Coccinellidae). Jaboticabal, 2002. 147p. Tese (Doutorado) - Faculdade de Ciências Agrárias e Veterinárias, Universidade Estadual Paulista "Julio de Mesquita Filho".

SILVA, R.A.; GUERREIRO, J.C.; BUSOLI, A.C. Comportamento de predação de Coccidophilus citricola Brèthes, 1905 (Coleoptera: Coccinellidae) sobre 
Aspidiotus nerii (Bouche) (Hemiptera: Diaspididae). In: ENCONTRO CIENTÍFICO DE PÓS-GRADUAÇĀO DA FCAV, 3, Jaboticabal, 2001. Resumos// Jaboticabal: APG/FUNEP, 2001 p 34.

SILVA, R.A.; GUERREIRO, J.C.; MICHELOTTO, M.D.; BUSOLI, A.C. Desenvolvimento e comportamento de predação de Coccidophilus citricola Brèthes, 1905 (Coleoptera: Coccinellidae) sobre Aspidiotus nerii Bouché, 1833 (Hemiptera: Diaspididae). Boletín de Sanidad Vegetal Plagas, v.29, n. 1, p.9-15, 2003.

SILVEIRA NETO, S.; NAKANO, O.; BARBIN, D.; VILLA NOVA, N.A. Manual de ecologia dos insetos. São Paulo: Agronômica Ceres, 1976. 419p.

SLOGGETT, J.J.; MAJERUS, M.E.N. Habitat preferences and diet in the predatory Coccinellidae (Coleoptera): an evolutionary perspective. Biological Journal of the Linnean Society, v.70, p.63-88, 2000.

TOSTOWARYK, W. The effect of prey defense on the functional response of Podisus modestus (Hemiptera: Pentatomidae) to densities of the sawflies Neodiprion swainei and N. prattibanksianae (Hymenoptera: Neodiprionidae). The Canadian Entomologist, v.104, p.61-69, 1972.

VANDENBERG, N.J. A systematic study of Olla Casey and allied genera of the new world (Coleoptera: Coccinellidae). Berkeley, 1987. 328p. Thesis(Ph.D) - University of California.

van den BOSCH, R.; SCHLINGER, E.I.; DIETRICH, E.J.; HALL,I.M. The role of imported parasites in the biological control of the spotted alfafa aphid in southern California in 1957. (Coccinellid activity). Journal of Economic Entomology, v.52, p.142-154, 1959. 
VIEIRA, G.F.; BUENO, V.H.P.; AUAD, A.M. Resposta funcional de Scymnus (Pullus) argentinicus (Weise) (Coleoptera: Coccinellidae) a diferentes densidades do pulgão verde Schizaphis graminum (Rond.) (Homoptera: Aphididae). Anais da Sociedade Entomológica do Brasil, v.26, n.3, p.495-502, 1997.

WISSINGER, S.A. Cyclic colonization in predictably ephemeral habitats: a template for biological control in annual crop systems. Biological Control, v.10, p.4-5, 1997.

YAKOMI, R.K.; LASTRA, R.; STOETZEL, M.B.; DAMSTEEGT, V.D.; LEE, R.F.; GARNSEY, S.M.; GOTTWALD, T.R.; ROCHA-PEÑA, M.A.; NIBLETT, C.L. Establishment of the Brown citrus aphid (Homoptera: Aphididae) in Central America and the caribbean basin and transmission of citrus tristeza virus. Journal of Economic Entomology, v.87, n.4, p.1078-1085, 1994. 
